\title{
Option-implied expectations in commodity markets and monetary policy
}

\author{
Athanasios Triantafyllou ${ }^{\mathrm{a}}$ and George Dotsis ${ }^{\mathrm{b}}$
}

\begin{abstract}
In this paper we estimate the dynamic interactions between option-implied variance and skewness in agricultural commodity markets and monetary policy. Using a structural vector autoregressive (SVAR) framework, we find that an expansionary (contractionary) monetary policy upwardly (downwardly) revises commodity markets' expectations about the price and volatility path of agricultural products. On the other hand, our empirical analysis reveals that monetary policy does not have a systematic and timely response to sudden changes in option implied expectations of commodity investors. In addition, we provide empirical evidence showing the robust forecasting power of agricultural option-implied information on monetary policy with $\mathrm{R}^{2}$ values reaching almost $52 \%$.
\end{abstract}

Key words: Monetary Policy, Implied Variance and Skewness, Agricultural Commodities JEL classification: E4, G1, Q1

This work was carried out at the Department of Economics of University of Athens and it is supported by the Special Account Research Grant 11105.

a PhD candidate, Department of Economics, University of Athens, triant.ath@ gmail.com, tel:2109953506,

b Corresponding Author, Assistant Professor in Finance, Department of Economics, University of Athens, 10562, Greece, tel: +30 2103689454, gdotsis@econ.uoa.gr 


\section{Introduction}

Empirical and theoretical studies have shown that monetary policy is an important determinant of commodity prices (see, for example, Frankel, 1986; Frankel and Rose, 2010). Frankel (2013) argues that the lax monetary policy of the Fed during the recent period (2003-2013) was an important factor that contributed significantly to the rapid rise in almost all commodity prices. He provides a subtle economic interpretation of the factors that induce the negative statistical relationship between interest rates and commodity prices. Low interest rates increase the demand or decrease the supply of storable commodities because low interest rates decrease the incentive for extraction today versus tomorrow (real options effect), they decrease the cost of carrying inventories and lead to a portfolio rebalancing from bonds towards commodity markets.

The general consensus in the literature is that an expansionary (contractionary) monetary policy stance is usually associated with high (low) commodity prices. Anzuini, Lombardi and Pagano (2013) use a standard VAR analysis and examine the impact of US monetary policy shocks on commodity prices. They find that an expansionary monetary policy shock increases modestly commodities prices. Gubler and Hertweck (2013) provide empirical evidence that an expansionary monetary in US induces a persistent increase in commodity prices and Gilbert (2010) shows that "agricultural price booms" are better explained by macroeconomic and monetary factors instead of commodity-specific factors. Hammoudeh, Nguyen and Sousa (2015) find that a contractionary US monetary shock leads to an immediate rise in energy and metals prices and to an initial rise which reverses to a fall in agricultural commodity prices, implicitly identifying a sectorial inflation monetary policy channel. 
Gospodinov and Jamali (2013) use commodity futures data and find that US expansionary monetary policy surprises tend to increase commodity prices. However, they document that the sensitivity to monetary shocks varies significantly across different commodity groups. Gordon and Rowenhorst (2006) show that commodities is the asset class which acts as the most efficient hedge against both the expected and the unexpected component of inflation, and Frankel and Hardouvelis (1985) find that when inflation expectations are upwardly revised (expansionary monetary policy), "investors to protect themselves will shift out of money and into commodities, thus driving up current commodity prices". In addition, we identify in the literature the reverse channel of causality, according to which commodity prices are early warning signals of changes in monetary policy and of future inflationary pressures (Awokuse and Yang, 2003; Bhar and Hamori, 2008; Frankel, 2008; Cody and Mills, 1991; Garner, 1989; Gospodinov and Ng, 2013).

In this paper we focus on the effects of monetary policy shocks on agricultural commodity markets. Agricultural commodities are homogeneous products which have perfect price flexibility and usually overreact to monetary announcements ${ }^{1}$. Bordo (1980) shows that the prices of raw goods (like agricultural commodities) have a much quicker response to changes in the money supply compared to the manufactured goods. Frankel (1986) gives further theoretical and empirical support of this view by stating that "monetary policy has important effects on agricultural commodity prices,

\footnotetext{
${ }^{1}$ The economic reasoning behind choosing agricultural commodities is that agricultural commodity prices move faster and have a more instant response to monetary policy shocks compared to the other services of manufactured goods and services which are included in the CPI. Okun (1975) was the first who identified the flexibility of raw commodity prices when compared to the relatively 'sticky' prices of the rest manufacturing goods and services which are included in the CPI. According to Okun (1975), the manufacturing goods have sticky prices since they are differentiated products traded in imperfect markets while the raw commodities are homogeneous products traded in perfectly competitive markets. Because of this perfect price flexibility, agricultural commodity price fluctuations act as a potential measure of market's perception of inflation and monetary expectations.
} 
because, though they are flexible, other goods prices are sticky". Frankel (1986) and Saghaian, Reed and Marchant (2002) use the Dornbusch (1976) model and find that the highly flexible agricultural commodities 'overshoot' in response to monetary policy shocks. Robertson and Orden (1990) find that an unanticipated monetary policy shock has a significant short-run impact in favor of agricultural commodity prices (when compared to the impact on the prices of the manufacturing goods) which vanishes in the long-run, while Chambers and Just (1992) find that the lax monetary policy has a negative effect on maize, wheat and soybeans prices. Furthermore, Frankel (2008) finds that the prices of agricultural and mineral commodities are negatively related to the level of short-term real interest rates and identifies the expansionary monetary policy as a key factor of the 2006-2008 agricultural and mineral commodity market boom.

In this paper we take the current research one step further by linking US monetary policy not with commodity prices, but with the option-implied expectations about the future distribution of commodity prices. We focus on option implied variance and option implied skewness extracted from the maize, wheat and soybeans ${ }^{2}$ commodity derivative market. We use implied variance as an ex-ante measure of investor's expectations about the future variance of agricultural commodity prices. However,

\footnotetext{
${ }^{2}$ We choose maize, wheat and soybeans commodity markets in our empirical analysis because these agricultural commodities are a sound proxy for agricultural commodity markets in the relevant literature. Although many empirical works which focus on commodity markets use a cross section of around 12 agricultural commodities (e.g. Daskalaki, Kostakis and Skiadopoulos (2014); FernandezPerez, Fuertes and Miffre (2016)), we include the three most important (in terms of liquidity of their respective options and futures markets) which are the maize, wheat and soybeans futures and options markets. Maize, wheat and soybeans have the most liquid futures and options market (in both terms of trading volume and open interest) compared with the respective derivative markets of the rest agricultural commodities. Since we base our empirical analysis to the option-implied expectations, we choose these three agricultural commodity because they have the more reliable and liquid futures and options market. In addition, a large number of empirical works which focuses on the information content of agricultural derivative market uses maize, wheat and soybeans futures and options markets (Chambers and Just (1992), Simon (2003)).
} 
investor's expectations extracted from the options market may embed both risk aversion and objective expectations about future variance. To address this issue, in the empirical analysis we also decompose the implied variance into an objective expectation about future variance and a residual called variance risk premium which proxies for risk aversion ${ }^{3}$. Option implied skewness is used as an ex-ante measure which quantifies expectations about the future price path of commodity prices. For example, Han (2008) finds that in the S\&P 500 equity option market implied skewness is highly positively correlated with market sentiment. In our empirical analysis we view a positive implied skewness as a signal that reveals a bullish market and we consider a negative implied skewness as a signal that reveals a bearish commodity market. $^{4}$

Our empirical investigation is motivated by studies that identify the crucial importance of the 'risk taking channel of monetary policy' (Andrian and Shin (2008), Angeloni, Faia and Lo Duca (2015), Borio and Lowe (2002), Bruno and Shin (2015), Bekaert, Hoerova and Lo Duca (2013), Borio and Zhu (2012), David and Veronesi (2014), Jimenez, Ongena, Peydro, and Saurina (2014), Mishkin and White (2002), Rajan (2006)). These empirical works identify the structural linkages between the monetary

\footnotetext{
${ }^{3}$ The respective works on the literature on risk aversion on commodity markets define the Variance Risk Premium (VRP) in an individual commodity market as the compensation demanded by a representative investor in the respective commodity market in order to bear variance risk (Doran and Ronn (2008), Trolle and Schwartz (2010), Prokopczuk, and Simen (2014), Wang, Fausti and Qasmi (2012)). In our study the VRP for each individual commodity has the same economic interpretation since they represent the time-varying degree of risk aversion of investors and producers in a specific commodity market (e.g. maize). Our interpretation of the VRP has the same economic meaning with the VRP which is computed for the equity market using the S\&P500 index (Carr and Wu (2009), Bekaert, Hoerova and Lo Duka (2013)), with the only difference being that our measure is commodity (asset) specific and does not refer to the agricultural commodity market as a whole. Unlike the equity market, in commodity markets there is not available a traded commodity market index and an option contract written on the index. For this reason, it is impossible to construct a widely accepted and reliable measure of risk aversion for the agricultural commodity market as a whole.

${ }^{4}$ When option-implied skewness increases, option writers increase the likelihood of future increase in the price of the underlying asset (calls are more expensive relative to puts) and vice-versa. For more details see Bakhsi, Kapadia and Madan (2003) and Rehman and Vilkov (2012).
} 
policy stance and the perception and pricing of risk by financial market participants. For example, Bruno and Shin (2015) show the dynamical links between the monetary policy stance and the leverage in the banking sector and attribute a large part of this leverage effect to fluctuations in credit risk-taking. Angeloni, Faia and Lo Duca (2015) find that an expansionary monetary policy results to an increase in the risk taking in the banking sector. In addition, Bekaert, Hoerova and Lo Duca (2013) and David and Veronesi (2014) show that monetary policy shocks have a significant impact on the time-varying degree of risk aversion in the equity market. While the relevant empirical works verify the existence of a risk taking channel of monetary policy in the equity market and in the banking sector, there is no empirical work examining the existence of this risk-taking monetary policy channel for commodity markets. Our econometric analysis is the first which sheds light on the effects of monetary policy shocks on commodity market uncertainty and risk aversion. Our study is methodologically most closely related to the work of Bekaert, Hoerova and Lo Duca (2013) who study structural interdependencies between monetary policy and option-implied measures of risk aversion and volatility in the S\&P 500 equity option market. In the empirical analysis we use a structural vector autoregressive (SVAR) framework to search the dynamic interactions between expectations about future variance and skewness in agricultural commodity markets and monetary policy. The stance of monetary policy is proxied by the Fed funds rate or other alternative measures like the real interest rate, the short-term US-Treasury Bill and the state of inflation expectations. ${ }^{5}$ To the best of our knowledge, this is the first study which examines the dynamic interactions between commodity option-implied variance and skewness and monetary policy.

\footnotetext{
${ }^{5}$ Bernanke (2007): "Undoubtedly, the state of inflation expectations greatly influences actual inflation and thus the central bank's ability to achieve price stability."
} 
We find that unlike stock markets for which Bernanke and Kuttner (2005) and Bekaert, Hoerova and Lo Duca (2013) find that a lax monetary policy decreases risk aversion and option implied variance in the short to medium run (after about 6 months), in agricultural commodity markets an expansionary (contractionary) monetary policy increases (decreases) implied variance and makes more positive the skewness of the risk neutral distribution of agricultural commodity markets in the short to medium run (after 4-7 months). In other words, we empirically verify that expectations in commodity markets have an opposite reaction to monetary shocks compared with those in the stock-market. The economic interpretation behind this contrast in stock-market and commodity market reactions to monetary shocks lays in the fact that while an expansionary monetary policy (low interest rates) leads to increases in equity and commodity market prices, it has an exact opposite effect to the volatility of equity and commodity prices. In the equity market, good news about prices (a rising stock-market) reduce volatility in the market due to the 'leverage effect' (Christie (1982)). According to the 'leverage effect', a rising the stock-price decreases the firms' leverage and makes the firm less risky, or equivalently, less volatile. In commodity markets, the price-volatility correlation turns to positive because in commodity markets rising prices result to increasing market turbulence and uncertainty about these prices. The mechanics which link prices and the respective volatility in commodity markets have their roots in the 'Theory of Storage (Kaldor (1939), Brennan (1958), Telser (1958), Working (1948, 1949), Fama and French (1987), Deaton and Laroque (1992), Gordon, Hayashi and Rowenhorst (2013)). According to the 'Theory of Storage', the decline in inventory levels increases the marginal convenience yield for holding physical inventory which results to rising risk premia and uncertainty about commodity prices. According to this theory, the 
inventory level of an individual commodity is inversely related to commodity market turbulence which in commodity markets (unlike the stock-market) is translated as the contemporaneous upward movement of the respective commodity prices and volatility ${ }^{6}$

We additionally find that the degree of 'bullishness' (option-implied skewness) of agricultural markets is more sensitive to monetary shocks compared to implied variance. The increased sensitivity of risk neutral skewness might result from the fact of the already empirically verified negative correlation between agricultural and mineral commodity prices and US short-term interest rates (Frankel (2008), Frankel and Rose (2010)). Our results on the significant negative impact of monetary shocks on the risk neutral skewness of agricultural markets shows the increased significance of monetary shocks on the risk neutral expectations about future commodity prices. On the other hand, David and Veronesi (2014) empirically show that the optionimplied expectations about future prices in the stock-market are not significantly affected by monetary policy shocks ${ }^{7}$. While an expansionary monetary policy (a negative interest rate shock) has a positive effect in stock-market prices (Bernanke and Kuttner (2005), Rigobon and Sack (2004)) and in commodity prices (Gordon and Rowenhorst (2006), Frankel (2008), Frankel and Rose (2010)), we show that the

\footnotetext{
${ }^{6}$ Deaton and Laroque (1992) estimate a storage model and show that the decrease in inventory levels (the higher probability of a stock-out in inventories) is associated with rising risk premia, commodity prices and expected future spot price volatility in the respective commodity markets. In addition, Gordon, Hayashi and Rowenhorst (2013) provide recent empirical evidence in support of the Deaton and Laroque (1992) findings according to which the inventory level and the marginal convenience yield for holding physical inventory are the key factors behind the contemporaneous and parallel time series movements of commodity prices and of the volatility processes of these prices.

${ }^{7}$ David and Veronesi (2014) estimate a bivariate VAR model with the 3-month US Treasury Bill and the put/call ratio (the ratio of out-of-the-money put and call option prices) of the S\&P 500 option contract. The put/call ratio has a similar economic interpretation compared to our risk neutral skewness since it quantifies investors' fears about stock-market declines. They find that the responses of the put/call ratio to shocks on the US-Treasury bill rate are insignificant.
} 
analogous positive effect exists for agricultural commodity expectations about these prices, but, according to recent empirical evidence of David and Veronesi (2014), does not exist in the stock-market. In simpler words, our empirical analysis is the first to show that the management (by the US monetary authority) of market expectations about future prices, while being infeasible for the case of the stock-market, becomes feasible when dealing with maize, wheat and soybeans market expectations. We additionally examine the dynamic interactions between monetary policy and commodity investors' perceptions about tail risk which we quantify by estimating the kurtosis of the risk neutral distribution. Our SVAR model shows that, unlike risk neutral variance and skewness, the risk neutral kurtosis does not have a significant response to monetary policy shocks.

Our main findings do not change when instead of the Fed funds rate we use other widely accepted alternative measures of the monetary policy stance, like the real interest rate, the 3-month US-Treasury Bill rate and the state of short-term inflation expectations. Our empirical analysis reveals that a positive one standard deviation shock in implied variance has sometimes a very sluggish effect on monetary policy in some of the VAR identification schemes. We do not find any statistically significant effects from implied skewness to monetary policy. Overall, our results indicate that there is no systematic response of monetary authorities to a sudden change in maize, wheat and soybeans market expectations. While the monetary authority reacts to a highly risk averse and volatile stock-market by lowering interest rates (see Bekaert, Hoerova and Lo Duca (2013), David and Veronesi (2014)), we empirically show that 
the monetary authority does not systematically intervene in order to calm down the turbulence and the expectations about an individual agricultural commodity price. ${ }^{8}$

Furthermore, following the approach of Bekaert, Hoerova and Lo Duca (2013), we also estimate a multivariate VAR in which we control for business cycles and we decompose option-implied variance into economic uncertainty (expected realized variance of commodity prices) and a residual called variance risk premium which proxies for risk aversion. ${ }^{9}$ We find that option-implied expectations respond instantly (after 2-4 months) to monetary shocks with the responses remaining statistically significant for many months after the initial shock. These results show that monetary policy is able to affect commodity market expectations irrespective of the phase of the business cycle. When we decompose the option-implied variance to its two components we find that the risk aversion component has an instant and statistically significant positive response to negative monetary policy shocks in maize and soybeans markets. In the wheat market the economic uncertainty component instead of the risk aversion is more sensitive monetary policy shocks. Our findings implicitly reveal that monetary authorities, in addition to being able to affect commodity price trends (Bessler, 1984; Frankel and Hardouvelis, 1985; Pindyck and Rotemberg, 1990; Hua, 1998) can also control the (option-implied) expectations of agricultural

\footnotetext{
${ }^{8}$ Our VAR models show that the monetary policy responses to a positive shock to option-implied expectations and to risk aversion are sluggish, not persistently negative or positive and in many cases statistically insignificant. These empirical results show that monetary authorities do not (at least for the time-being) systematically intervene in order to calm down the expectations about an individual commodity price. This result is somewhat expected since we do not expect the monetary authority to react to changes in an individual commodity market. For this reason, our results are not directly comparable to those of David and Veronesi (2014) and Bekaert, Hoerova and Lo Duca (2013) since they refer to the monetary effects on the option-implied expectations of the stock-market as a whole (quantified by using the options contracts on the S\&P 500 and the VIX index).

${ }_{9}$ Option-implied variance incorporates both economic uncertainty and risk aversion. Variance Risk Premium (VRP) is a more reliable measure of risk aversion, since it represents the compensation demanded by investors in order to bear variance risk (see Bliss and Panigirtzoglou (2004), Carr and Wu (2009)).
} 
commodity investors, which is an indirect (but feasible) way to control the actual price and volatility path in commodity markets. The latter can be achieved under a flexible inflation targeting regime which allows the short-term targeting of other variables besides inflation. ${ }^{10}$ Under this approach, we argue that the targeting of the optionimplied expectations of agricultural commodity markets will implicitly lead to less uncertainty and turbulence in these markets, which, ultimately, will result to a more stable inflation and production process (since the agricultural products are significant components of the Consumer Price Index and of the Industrial Production Index). The main policy implication behind our empirical findings is that the short-term targeting of the option-implied expectations of commodity markets can be an implicit shortterm target by the central bank in order to achieve its primary goals which is output and inflation stability.

In the last part of the empirical analysis we examine if agricultural option implied variance and skewness are robust predictors of the future monetary policy stance. We find a negative and statistically significant relationship between option-implied variance and skewness and future (from one month up to two years) monetary policy stance. Our results remain robust when we control for macroeconomic fundamentals, for expectations in stock market volatility (VIX), for the persistence of monetary policy stance and for the zero lower bound environment. We additionally find that the option-implied expectations are robust predictors of alternative measure of monetary

\footnotetext{
${ }^{10}$ Under a flexible inflation targeting regime, the monetary authority incorporates a concern for output stability while having the long-term inflation stability as primary long-term target. In addition, many researchers in the field state that the central bankers can better achieve their primary macroeconomic objectives (of inflation and output stabilization) when targeting other variables which are linked with financial stability like asset prices and credit growth (Borio and Lowe (2002), Jimenez, Ongena, Peydro and Saurina (2014)). Bernanke and Gertler (1999) mention that "the main advantage of flexible inflation targeting is that it provides a unified framework both for making monetary policy in normal times, and for preventing and ameliorating the effects of financial crises."
} 
policy stance, like inflation expectations, the 3-month US Treasury Bill rate and the short-term real interest rate. The predictive regressions employed in the empirical analysis do not suffer from endogeneity problems. The forecasting power of implied variance and skewness is not a consequence of the Feds systematic response to changes in expectations of option commodity market participants, since there exists no empirical evidence supporting the latter. The SVAR analysis reveals a sluggish, nonsystematic (not always negative) and in many cases statistically insignificant response of monetary policy to shocks in option-implied variance and skewness. Following the results and the claims of Woodford (1994) according to which only the non-standard indicators of monetary policy are the ones who can be used for monetary policy forecasting $^{11}$, we conclude that agricultural commodity option markets are able to give valuable information about the future path of monetary policy. The reason behind this option-implied macroeconomic informational content lies in the contemporaneous linkages between interest rates and real agricultural commodity prices (Calvo (2008), Frankel, 2008; Frankel and Rose, 2010; Frankel, 2013) according to which low real interest rates (lax monetary policy) lead to high real agricultural commodity prices. When for example commodity option writers (correctly) anticipate an upward trend in future interest rates, they give higher probability to a fall in commodity prices instead

\footnotetext{
11 Woodford (1994) claims that the ability of monetary policy indicators to "signal the underlying sources of inflationary pressures that one wants to respond to may be impaired by the very fact that the monetary authority responds to it". Woodford (1994) states that the predictive ability and increased significance of the nontraditional monetary policy indicators like the commodity prices, lies in the fact that these indicators are not causal determinants of monetary policy and inflation, but they are strongly affected by monetary policy and inflation expectations, and hence, they correctly anticipate and signal their future state. According to Woodford (1994), the absence of causal relationships in the forecasting regressions on monetary policy is the key behind choosing the appropriate indicators. This is the case for our risk neutral moments, since, they are strongly affected by monetary policy shocks and the relationship between risk neutral moments and the subsequent monetary policy stance is not causal, since the option-implied expectations in commodity markets are not a monetary policy target. Our SVAR analysis reveals the same information, since we find that the monetary authority does not respond to changes in risk neutral variance and skewness of agricultural commodity markets. Thus, the risk neutral variance and skewness of agricultural markets can be used as nonstandard (and hence useful) indicators of the future state of the monetary policy stance.
} 
of rise, a fact which makes more negative the skewness of option-implied risk neutral distributions.

The policy implication behind the significant forecasting performance of risk neutral variance and skewness is that the option-implied expectations of agricultural commodity markets can be useful monetary policy tools not only under a flexible inflation targeting regime, but also under a strict (or 'inflation forecast") targeting regime which fully concentrates on the targeting of inflation expectations ${ }^{12}$. According to this approach, the monetary authority can implicitly control inflation expectations by responding to changes in option-implied expectations of commodity markets, since these expectations have an instant response to monetary shocks and they are robust indicators of inflation expectations. In conclusion, under both strict and flexible inflation targeting framework, we argue that the central bank has always an incentive to use as monetary policy indicators the option-implied expectations of commodity markets since, besides implicitly leading to a stable inflation and production process (under a flexible inflation targeting regime), they are statistically significant predictors of expected inflation whose stability is the only objective of the central bank under a strict inflation targeting regime.

The remainder of the paper is structured as follows. In Section 2, we describe the analytical methodology for computing model-free option-implied variance and

\footnotetext{
${ }^{12}$ Under a strict inflation targeting regime (or "inflation forecast targeting"), the monetary authority should not respond to changes in asset prices. Under the strict inflation targeting, the central bank has the inflation forecast as the primary target (and puts zero weight on output stabilization). The empirical work of Bernanke and Gertler (1999) shows that the strict and aggressive inflation targeting framework achieves better output and inflation stabilization "when asset prices are volatile, whether the volatility is due to bubbles or to technological shocks; and that, given an aggressive response to inflation, there is no additional benefit to responding to asset prices". According to Bernanke and Gertler (1999), the monetary authority should respond to changes in asset prices only when these changes are early warning signals of inflationary pressures, since, by this way, the monetary authority implicitly targets inflation expectations.
} 
skewness and we describe the data. In Section 3 we present some descriptive statistics and we analyze the results of our SVAR models and the results of our predictive regressions of implied variance and skewness on monetary policy. Section 4 provides various robustness to our empirical results. Finally, Section 5 concludes and presents some policy implications and suggestions for further research.

\section{Methodology and Data}

\subsection{Model-Free Option-Implied Variance and Skewness}

We compute the model-free version of option implied variance and skewness using the method of Bakhsi, Kapadia and Madan (2003). Under the risk-neutral probability measure $Q$, the analytical formulas for conditional risk neutral moments are given in the equations (1), (2) and (3) below:

$$
\begin{gathered}
V A R=E_{t}^{Q}\left(\mathrm{R}^{2}\right)-\left[E_{t}^{Q}(\mathrm{R})\right]^{2} \\
S K E W=\frac{E_{t}^{Q}\left(R^{3}\right)-3 E_{t}^{Q}(R) E_{t}^{Q}\left(R^{2}\right)+2\left[E_{t}^{Q}(R)\right]^{3}}{V A R^{3 / 2}} \\
I K=\frac{E_{t}^{Q}\left(R^{4}\right)-4 E_{t}^{Q}(R) E_{t}^{Q}\left(R^{3}\right)+6 E_{t}^{Q}(R) E_{t}^{Q}\left(R^{2}\right)-3\left[E_{t}^{Q}(R)\right]^{4}}{I V^{2}}
\end{gathered}
$$

In accordance with Bakshi, Kapadia and Madan (2003), the "Quad", "Cubic" and

"Quart" are hypothetical contracts which represent the expected (under the risk 
neutral probability measure $(Q)$ ) discounted quadratic, cubic and quartic returns of the futures contracts and they are given in equations (4) to (6) below ${ }^{13}$ :

$$
\begin{gathered}
\text { Quad }=e^{-r(T-t)} E_{t}^{Q}\left(R^{2}\right) \\
\text { Cubic }=e^{-r(T-t)} E_{t}^{Q}\left(R^{3}\right) \\
\text { Quart }=e^{-r(T-t)} E_{t}^{Q}\left(R^{4}\right)
\end{gathered}
$$

In the equations (4) and (5) and (6), $r$ is the risk-free interest rate (3-month USTreasury Bill), $t$ is the trading date and $T$ is the expiration date of a given contract and consequently $T-t$ defines time to maturity. Solving for the quadratic risk neutral expected returns $\left(E_{t}^{Q}\left(R^{2}\right)\right)$, the cubic risk neutral expected returns $\left(E_{t}{ }^{Q}\left(R^{3}\right)\right)$ and quartic risk neutral expected returns $\left(E_{t}^{Q}\left(R^{4}\right)\right)$ given in equations (4), (5) and (6) and replacing these quantities into equations (1), (2) and (3), we get the model-free version of option implied variance (IV), implied skewness (IS) and implied kurtosis (IK) as a function of Quad, Cubic and Quart contracts and risk neutral expected returns $\left(E_{t}^{Q}(R)\right)$ :

$$
\begin{gathered}
I V=e^{r(T-t)} \text { Quad }-\left[E_{t}^{Q}(R)\right]^{2} \\
I S=\frac{e^{r(T-t)} C u b i c-3 E_{t}^{Q}(R) e^{r(T-t)} Q u a d+2\left[E_{t}^{Q}(R)\right]^{3}}{I V^{3 / 2}}
\end{gathered}
$$

\footnotetext{
${ }^{13}$ If we define with $R$ the logarithmic returns of the underlying asset with price $S_{t}\left[R=\ln \left(\left(S_{t+1} / \ln \left(S_{t}\right)\right)\right]\right.$, then a Quad (or volatility) contract is a theoretical contract with risk neutral quadratic expected return $\mathrm{E}_{\mathrm{t}}^{\mathrm{Q}}\left(\mathrm{R}^{2}\right)$, a Cubic contract is a contract with risk neutral cubic expected return $\mathrm{E}_{\mathrm{t}}^{\mathrm{Q}}\left(\mathrm{R}^{3}\right)$ and a Quart contract is a contract with risk neutral quartic expected return $\mathrm{E}_{\mathrm{t}}^{\mathrm{Q}}\left(\mathrm{R}^{4}\right)$. Bakhsi, Kapadia and Madan (2003) prove that quadratic, cubic and quartic expected risk neutral returns are continuous functions of out of the money (OTM) call and put option prices.
} 


$$
I K=\frac{e^{r(T-t)} Q u a r t-4 E_{t}^{Q}(R) e^{r(T-t)} C u b i c+6 E_{t}^{Q}(R) e^{r(T-t)} Q u a d-3\left[E_{t}^{Q}(R)\right]^{4}}{I V^{2}}
$$

Furthermore, Bakhsi, Kapadia and Madan (2003) show that under the risk-neutral pricing measure Q, the "Quad", "Cubic" and "Quart" contracts can be expressed as continuous functions of out-of-the-money European calls $\mathrm{C}(t, T, K)$ and out-of-themoney European puts $P(t, T, K)$ in the form given below :

Quad $=\int_{F}^{\infty} \frac{2\left(1-\ln \left[\frac{K}{F}\right]\right)}{K^{2}} C(t, T, K) d K+\int_{0}^{F} \frac{2\left(1+\ln \left[\frac{F}{K}\right]\right)}{K^{2}} P(t, T, K) d K$

Cubic $=\int_{F}^{\infty} \frac{6 \ln \left(\frac{K}{F}\right)-3 \ln \left(\frac{K}{F}\right)^{2}}{K^{2}} C(t, T, K) d K-\int_{0}^{F} \frac{6 \ln \left(\frac{F}{K}\right)+3 \ln \left(\frac{F}{K}\right)^{2}}{K^{2}} P(t, T, K) d K$

Quart $=\int_{F}^{\infty} \frac{12 \ln \left(\frac{K}{F}\right)^{2}-4 \ln \left(\frac{K}{F}\right)^{3}}{K^{2}} C(t, T, K) d K-\int_{0}^{F} \frac{12 \ln \left(\frac{F}{K}\right)^{2}+4 \ln \left(\frac{F}{K}\right)^{3}}{K^{2}} P(t, T, K) d K$

Where $K$ is the strike price of the option contract, $F$ is the price of the underlying futures contract, $t$ is the trading date and $T$ is the expiration date of the option contract. In addition, Bakhsi, Kapadia and Madan (2003) prove that the expected conditional risk-neutral return $E_{t}^{Q}(R)$ can be approximated by the following expression: 


$$
E_{t}^{Q}(R)=e^{r(T-t)}-1-\frac{e^{r(T-t)}}{2} Q u a d-\frac{e^{r(T-t)}}{6} \text { Cubic }
$$

Knowing the analytical forms of "Quad" and "Cubic" and "Quart" contracts from equations (10), (11) and (12), and the approximating quantity of conditional risk neutral expected returns $E_{t}^{Q}(R)$ from equation (13), we can compute by using numerical integration the model-free implied variance (IV), implied skewness (IS) and implied kurtosis (IK) which are given in equations (7), (8) and (9) respectively.

\subsection{Commodity Futures and Options Data}

We obtain end-of-month option and futures data for maize, wheat and soybeans from the Chicago Board of Trade (CBOT). The options and futures data for maize, wheat and soybeans cover the period from January 1990 to December 2011. From our data sample we eliminate call and put options prices with moneyness level less than $80 \%$ $(K / F<0.8)$ and call options with moneyness level greater than $120 \%(K / F>1.2)$. Thus, the [ 0.8 1.2] moneyness band corresponds to our time series dataset of out of the money (OTM) call and put commodity option prices ${ }^{14}$. We then use the Black (1976) model in order to compute implied volatilities for our selected option contracts. Following Jiang and Tian (2005) and Chang, Christoffersen, Jacobs and Vainberg (2012), we use the cubic spline method in order to interpolate-extrapolate these implied volatilities for each maturity across all the selected moneyness levels. We construct a fine grid of 1001 moneyness levels with a band ranging between $50 \%$ and $300 \%$, and for these moneyness levels we create a (corresponding) grid of 1001

\footnotetext{
${ }^{14}$ The out-of-the-money (OTM) call option contracts are those with moneyness level larger than $100 \%$ $(K / F>1)$ and the OTM put options those with moneyness level smaller than $100 \%(K / F<1)$. Consequently, the [0.8 1 1] moneyness band corresponds to the OTM put option prices and the [1 1.2$]$ moneyness band corresponds to the OTM call option prices.
} 
implied volatilities. In order to get more reliable information from the grid of 1001 the moneyness -implied volatility pairs, we do not make any interpolation - extrapolation when the number of options for a given trading day and a given maturity date is less than four.

Using the Black (1976) formula for commodity option prices, we convert these 1001 implied volatilities into option prices. We use numerical trapezoidal integration to compute the Quad, Cubic and Quart contracts in (10), (11) and (12) and to compute expected conditional risk neutral returns in (13). We then use the prices of Quad and Cubic and Quart contracts and the conditional risk neutral returns $E_{t}^{Q}(R)$, in order to compute $I V, I S$ and $I K$ in (7), (8) and (9). Following Wang, Fausti and Quasmi (2012), we construct the constant two-month (60-day) model-free implied variance and skewness time series using the following linear interpolation formula:

$$
I V_{60}=\left(T_{1} I V_{1} \frac{T_{2}-T_{60}}{T_{2}-T_{1}}+T_{2} I V_{2} \frac{T_{60}-T_{1}}{T_{2}-T_{1}}\right) \times \frac{T_{365}}{T_{60}}
$$

Where $I V_{1}$ is the option-implied variance with maturity closest to 60 days, but less than 60 days, and $I V_{2}$ is the option-implied variance with maturity closest to 60 days but more than or equal to 60 days. $T_{1}$ and $T_{2}$ are time to expiration for $I V_{1}$ and $I V_{2}$, with $T_{1}<60$ and $T_{2} \geq 60 . T_{365}$ and $T_{60}$ are the 365 and 60 day intervals respectively. We follow the same interpolation method for the construction of the model free optionimplied skewness.

We also compute the 2-month realized variance of maize, wheat and soybean futures prices. The maturity of commodity futures has to be the same with commodity options 
written on them. If the nearby contract has less than 60 days to expiration, we replace it with the next deferred contract which always has more than (or equal to) 60 days to expiration, since expiration dates on commodity futures are $1^{\text {st }}$ of March, May, July, September and December. Thus, we choose commodity futures which have approximately a constant 2-month maturity. Following the methodology of Wang, Fausti and Qasmi (2012), we calculate the realized variance using daily closing prices of the nearby futures contract to get the best possible approximation of a fixed maturity of 60 days, according to the equation (15) below ${ }^{15}$ :

$$
R V_{t, T}=\frac{1}{T} \sum_{i=1}^{T}\left(\frac{F_{t+i}-F_{t+i-1}}{F_{t+i-1}}-\frac{\overline{F_{t+i}-F_{t+i-1}}}{F_{t+i-1}}\right)^{2}
$$

Where $F_{t}$ is the commodity futures price the trading day $\mathrm{t}$ and the time interval $(t, T)$ is the number of trading days during each monthly period. $R V_{t, T}$ is our estimated realized variance for the each monthly period.

\subsection{Macroeconomic and Stock Market Data}

We obtain monthly data for the Consumer Price Index (CPI), US unemployment rate, real wages, Industrial Production Index (IPI) and the Fed fund rate (FFR) from Federal Reserve Bank of Saint Louis. We obtain monthly short-term (with 1 year horizon) inflation expectations data from the Federal Reserve Bank of Cleveland. We construct the time series for the short-term real interest rate as the Fed funds rate minus the rate

\footnotetext{
${ }^{15}$ In the financial econometrics literature the realized variance (RV) is usually defined as the best discrete time estimator of the quadratic return variation $(\mathrm{QV})$ which is equal to the sum of the quadratic realized returns (Carr and Wu (2009)) for a given time period. This kind of estimation is usually applied when dealing with high-frequency intraday data for which the sum of quadratic returns converges more efficiently to the integrated quadratic return variation process (Barndorff-Nielsen and Sheppard (2002)). In our case, in which we deal with daily data, we choose the more appropriate methodology of measuring the realized variance as the monthly variance of daily commodity futures returns for the given month, as shown in equation (15).
} 
of inflation. Short-term (3-month) US Treasury-Bill data are downloaded from DataStream. We construct monthly overlapping data of 2-month growth of Industrial Production Index, real wages and CPI. All macroeconomic data have monthly frequencies and cover the period from January 1990 through December 2011. We obtain end-of-month data for the VIX index from Chicago Board Options Exchange (CBOE). The VIX index has a fixed maturity of 30 days and it is constructed by using the cross section of out-of-the-money call and put options on the S\&P 500 index.

\section{Empirical results}

\subsection{Descriptive statistics}

Table 1 reports the descriptive statistics for the realized variance (RV), implied variance (IV) and implied skewness (IS) in the maize, wheat and soybean market. Wheat has the highest average realized and implied variance and soybean has the highest average implied skewness. Maize is on average the most negatively skewed. Table 1 also presents the Augmented Dickey-Fuller (ADF) and the Philips-Perron (PP) test statistics. In each test the null hypothesis is that the time series variable has a unit root. The hypothesis of a unit root is rejected for all variables under consideration.

\section{[Insert Table 1 Here]}

Table 2 reports the correlation coefficients between the Fed funds rate and the optionimplied variance and skewness of maize, wheat and soybeans markets. From table 2 we observe that the risk neutral variance and skewness are highly positively correlated. The high degree of correlation between the risk neutral variance and 
skewness of different agricultural markets combined with the negative correlation coefficients between risk neutral variance and skewness and the Fed funds rate is a first empirical sign indicating that the factors which drive the dynamics in the optionimplied expectations in these market, are common, and most probably, associated with monetary policy and inflation expectations. The synchronous rises in commodity market expectations are the first empirical evidence showing that a common macroeconomic factor hides behind their common dynamics. These results are line with the empirical findings of Frankel (2008) and Frankel and Rose (2010) who empirically show that the lax monetary policy environment of the post 2000 period decade must be the most influential and common macroeconomic factor behind the 2000-2008 commodity market boom.

\section{[Insert Table 2 Here]}

Figure 1 plots the contemporaneous movements in the time series of the Fed fund rate and the implied skewness of maize, wheat and soybeans market during the period under investigation (1990-2011) and Figure 2 plot the contemporaneous movements between implied variance and the Fed fund rate. From Figures 1 and 2 we observe that a low (high) level of the Fed fund rate is associated with a high (low) implied skewness and high (low) implied variance. We additionally observe that after 2002 implied skewness turns from negative to positive in all three commodities under investigation, with the Fed fund rate reaching very low levels during the same period (monetary easing era). Overall, from figures 1 and 2 we see that time series dynamics and the monetary reactions of the option-implied expectations in agricultural markets are quite similar in terms of timing and magnitude. 
[Insert Figure 1 Here]

[Insert Figure 2 Here]

\subsection{Granger Causality}

We begin our econometric analysis with the results from Granger causality tests between monetary policy and option implied variance and skewness. The test is conducted with unrestricted bivariate VAR models which contain as endogenous variables the monetary policy stance and the option-implied variance or skewness of agricultural commodity markets. More specifically, we estimate a VAR of the form $Y_{t}=\left[F F R_{t} I V_{t}\right]$ or $Y_{t}=\left[F F R_{t} I S_{t}\right]$, where $F F R$ is the monthly Fed funds rate and represents the monetary policy stance, $I V$ is the monthly option-implied variance from maize, wheat or the soybeans markets and $I S$ is the implied skewness from maize, wheat or soybeans markets. The results are reported in Table (3).

[Insert Table 3 Here]

Granger causality tests in Table 3 indicate that the Fed fund rate causes the implied skewness in all markets under consideration (maize, grain and soybeans) while the reverse effect is insignificant. The Fed fund rate causes the implied variance in the maize markets, and the implied variance in all markets has a significant effect on the Fed funds rate. These preliminary tests indicate a significant directional effect from monetary policy to implied skewness and some mixed bi-directional effects in the case of implied variance. 


\subsection{Structural VARs}

We follow the approach of Bekaert, Hoerova and Lo Duca (2013) and we estimate structural bivariate VAR models of the form $Y_{t}=\left[F F R_{t} I V_{t}\right]$, or $Y_{t}=\left[\mathrm{FFR}_{t} \mathrm{IS}_{t}\right]$. In the VAR specification we place monetary policy first and implied variance or implied skewness second in order to capture the fact that monetary authorities respond more sluggishly to market-oriented shocks while on the other hand, asset markets in general are more sensitive to monetary shocks. We run our bivariate SVARs using long-run and short-run restrictions. For an $\mathrm{N}$ variable VAR, we need $\mathrm{N}(\mathrm{N}-1) / 2$ restrictions in order to be identified. Thus, for our bivariate SVARs, it is necessary to impose 1 restriction for their exact identification.

\section{$\underline{\text { Short-run restriction }}$}

We run bivariate SVARs using a short-run restriction, according to which expectations about future volatility or skewness in commodity markets do not have a contemporaneous (short-run) effect in monetary policy. In other words, we assume that monetary authorities have a sluggish response to changes in option-implied expectations of commodity markets (The empirical evidence we provide later are in favor of this argument-assumption). The bivariate SVAR with the short-run restriction is the following:

$$
B Y_{t}=\gamma_{0}+A Y_{t-1}+\varepsilon_{t}
$$

$Y_{t}$ is the matrix with the variables $Y_{t}=\left[F F R_{t} I V_{t}\right]$ or $Y_{t}=\left[\mathrm{FFR}_{t} \mathrm{IS}_{t}\right], \gamma_{0}$ is a $2 \mathrm{x} 1$ vector with constants $\left(\gamma_{0}=\left[\gamma_{01} \gamma_{02}\right]\right), \mathrm{B}$ is a $2 \times 2$ full-rank matrix which determines the 
endogeneity of the variables in our system and $\varepsilon_{t}$ is the matrix with the independent structural shocks in our system $\left(E\left(\varepsilon_{t} \varepsilon_{t}^{\prime}\right)=I\right)$. Lastly, A is the $2 \times 2$ short-run (feedback) response matrix in which we impose the short-run restriction according to which implied variance or implied skewness do not have a short-run effect on monetary policy. Our short-run restriction on the feedback matrix A is the following:

$$
A=\left[\begin{array}{ll}
a_{11} & 0 \\
a_{12} & a_{22}
\end{array}\right]
$$

\section{Long-run restriction}

Our long-run restriction has to do with the relevant literature on money neutrality (see Barro (1977), Barro (1978), Lucas (1972), Lucas (1976), Bernanke and Mihov (1998)). We restrict monetary policy to have a zero effect on option-implied expectations in the long-run. ${ }^{16}$ Bekaert, Hoerova and Lo Duca (2013) in their SVAR model make an analogous hypothesis-restriction about the zero long-run effects of monetary policy on the stock-market. Following Blanchard and Quah (1989), the SVAR model with the long-run restriction has the following long-run response matrix:

$$
C=\left(I-B^{-1} A\right)^{-1} B^{-1}
$$

Matrices $\mathrm{A}$ and $\mathrm{B}$ are already described in equation (16). We assume that monetary policy does not affect option-implied expectations in the long-run by placing the longrun restriction $\left(c_{21}=0\right)$ in the long-run response matrix $\mathrm{C}$ of the structural VAR of equation (16) of our bivariate SVAR as follows:

\footnotetext{
${ }^{16}$ According to Barro $(1977,1978)$ and Lucas $(1972,1976)$ money cannot affect real variables in the long-run because only unanticipated monetary shocks matter for the real economy. In the long-run, every change in monetary policy becomes anticipated by market participants.
} 


$$
C=\left[\begin{array}{cc}
c_{11} & \mathrm{c}_{12} \\
0 & \mathrm{c}_{22}
\end{array}\right]
$$

The coefficient $c_{21}=0$ restricts monetary policy to have zero effect on implied variance and skewness in the long-run. Additionally, we choose the optimal lag-length of our bivariate VARs by following the Akaike lag-length selection criterion ${ }^{17}$.

We base our results on reduced and structural-form Impulse response functions (IRFs and SIRFs respectively thereafter) for which we compute the 95\% Bootstrapped confidence intervals based on 1000 replications. We also estimate the IRFs from the unrestricted (reduced-form) bivariate VAR model. The results are reported in Table 4. Panel A reports the results from bivariate structural and reduced-form VARs with endogenous variables the Fed funds rate (FFR) and the implied variance (IV) and Panel B the results with the Fed funds rate (FFR) and implied skewness (IS). We present how many months the Impulse Response Functions (IRFs) generated by a negative one standard deviation shock in FFR or a positive one standard deviation shock in IV/IS remain statistically significant within the $95 \%$ confidence interval. Figure 3 plots the graphs of the IRFs for the case of FFR and IV (IV is measured in percentages) and Figure 4 plots the graphs of the IRFs for the case of FFR and IS.

\author{
[Insert Table 4 Here] \\ [Insert Figure 3 Here] \\ [Insert Figure 4 Here]
}

\footnotetext{
${ }^{17}$ When we choose the lag-length using the Schwarz (SBIC) criterion we obtain similar conclusions as those we present when using the Akaike criterion. The Schwarz criterion, compared to the Akaike criterion selects more parsimonious VARs.
} 
Several interesting conclusions emerge from observing the results regarding the empirical behavior of IRFs. Table 4 shows that a negative monetary shock has a significant positive effect in IV and IS in all markets considered (maize, wheat and soybeans). Both IV and IS display a fast response (after 4-8 months) to monetary policy shocks. Monetary policy shocks have a more long lasting impact on implied skewness compared to the impact on implied variance.

From Figure 3 we observe that a negative shock in the Fed funds rate (in the model with the short-run restriction) increases the implied variance of maize markets about 54.2 basis points after 7 months, increases the implied variance of wheat markets by 41.2 basis points after 3 months and increases implied variance of soybeans markets by 43.2 basis points after 7 months. These responses remain positive and statistically significant for many months after the initial monetary shock. For example, the IRFs of maize implied variance to a negative monetary shock remain statistically significant for 17 months (from the $8^{\text {th }}$ month till the $25^{\text {th }}$ month after the initial monetary shock) in the reduced form VAR, for 2 months (from the $8^{\text {th }}$ month till the $10^{\text {th }}$ month) in the SVAR with short-run restrictions and 15 months (from the $10^{\text {th }}$ month till the $25^{\text {th }}$ month) in the SVAR with long-run restrictions.

Implied skewness has also an almost immediate and persistent response to monetary policy shocks under all our VAR identification schemes. For example, from Figure 4 we see that a negative shock in the Fed fund rate increases the implied skewness of soybeans markets by 0.062 after 6 months. From Table 4 we see that this effect remains statistically significant from lag 6 up and till lag 32 in the model with the short-run restriction, and from lags 6-10 and 18-34 in the model with the long-run restriction. In addition, we estimate the structural-form Impulse Response Functions 
(SIRFs) of the bivariate SVAR models. Figure 5 plots the graphs of the SIRFs for FFR and IV and Figure 6 plots the graphs of the SIRFs between FFR and IS.

\author{
[Insert Figure 5 Here] \\ [Insert Figure 6 Here]
}

From figures 5 and 6 we observe that the SIRFs give nearly identical responses with the reduced-form IRFs of our bivariate SVAR models. Our basic conclusions remain unchanged when we estimate SIRFs instead of the IRFs which are shown in figures 3 and 4. Overall, our SVAR analysis reveals that the monetary policy effects on the bullishness (implied skewness) of maize and wheat markets are much more intensive and long-lasting compared to the monetary effects on implied variance. Our results indicate that the impact of monetary shocks on implied skewness is much greater compared to the impact on implied variance. In all the commodity markets we investigate and in all of our VAR identification schemes, implied skewness is being increased by a great amount in response to sudden shifts in monetary policy. This means that monetary authorities have the ability (under a flexible inflation targeting regime (see Bernanke and Gertler (1999)) to turn commodity option markets from bearish to bullish and vice-versa. In the section with the robustness tests we provide some additional empirical results which strengthen furthermore our claims about the ability of monetary authorities to turn commodity markets from bearish to bullish and vice-versa.

Our results are exactly opposite of those obtained by Bernanke and Kuttner (2005) and Bekaert, Hoerova and Lo Duca (2013) for the stock-market since they find that an 
expansionary monetary policy reduces uncertainty in equity markets. The economic interpretation behind this contradiction is that while in equity markets volatility and prices are negatively correlated (leverage effect), in commodity markets (and especially the storable ones), volatility and prices are positively correlated. As a result, an expansionary monetary policy (low interest rates) while raising equity and commodity market prices it does exactly the opposite to the volatility (risk) of these prices due to the opposite sign in the volatility-price correlation in the former ones compared to the latter ones. Thus, commodity investors revise upwards their expectations about volatility risk after observing a negative interest rate shock (expansionary policy), while equity investors revise downwards their expectations about volatility risk after observing the same shock. When studying the reverse channel of causality, we find that the responses of the Fed funds rate to positive variance shocks are sluggish and in most cases statistically insignificant. For example, for Table 3 we see that the monetary authority response is statistically significant 19 months after the initial shock in the best case. This fact implicitly reveals that monetary authorities, despite they systematically intervene in order to calm down equity markets by lowering interest rates, do not react in a systematic manner to a nervous and turbulent agricultural commodity market like the maize, wheat and soybeans market. In addition, in order to control for the dynamic interactions between risk neutral variance and skewness, we run a multivariate SVAR model in which we include the Fed funds rate, the risk neutral variance and the risk neutral skewness as endogenous variables. Our multivariate SVAR model is the following:

$$
B X_{t}=\delta_{0}+S X_{t-1}+\varepsilon_{t}
$$


Where $X_{t}$ is the matrix with variables $X_{t}=\left[F F R_{t} I V_{t} I S_{t}\right], \delta_{0}$ is a $3 \times 1$ vector with constants $\left(\delta_{0}=\left[\begin{array}{lll}\delta_{01} & \delta_{02} & \delta_{03}\end{array}\right]\right), \quad \mathrm{B}$ is a $3 \times 3$ full-rank matrix which determines the endogeneity of the variables in our system and $\varepsilon_{t}$ is the matrix with the independent structural shocks in our system $\left(E\left(\varepsilon_{t} \varepsilon_{t}^{\prime}\right)=I\right)$. Our short run restrictions are based on the same economic arguments and assumptions of long-run money neutrality which used for our bi-variate SVAR model presented in equations. In order for a 3 -factor SVAR to be exactly identified, we need to impose three restrictions. Thus, we again restrict monetary policy to have a zero long-run effect on risk neutral variance and risk neutral skewness, and we additionally assume that the monetary authority does not have a systematic short-term response to changes in risk neutral option-implied expectations of agricultural commodity markets. We impose one additional restriction according to which there are positive spillovers of equal magnitude from risk neutral variance to risk neutral skewness (the dynamic responses of variance shocks to risk neutral skewness is of the same sign and magnitude-this assumption is in line with the “Theory of Storage” (Brennan (1958), Telser (1958), Deaton and Laroque (1992)), according to which uncertainty and prices are positively correlated and to our empirical evidence (see table 2) which shows that the risk neutral variance and skewness time series processes are highly positively correlated. Our short-run feedback response matrix $S$ is given below:

$$
S=\left[\begin{array}{ccc}
s_{11} & 0 & 0 \\
S_{21} & S_{22} & s_{23} \\
S_{31} & 1 & S_{33}
\end{array}\right]
$$


Our long-run feedback matrix $L$ which is used for the model with the long-run restrictions (and its derivation is already described in equations (16) and (18)) is given below:

$$
L=\left[\begin{array}{ccc}
l_{11} & l_{12} & l_{13} \\
0 & l_{22} & s_{23} \\
0 & 1 & l_{33}
\end{array}\right]
$$

The Impulse Response Functions (IRFs) of our multivariate SVAR model (and of the respective reduce-form VAR model with the same VAR ordering in the endogenous variables) between monetary policy, risk neutral variance and risk neutral skewness are given in table 5 .

[Insert Table 5 here]

From table 5 we observe that our basic results and conclusions remain unaltered when we control for the dynamic interactions between risk neutral variance and skewness in our 3-factor SVAR model. The risk neutral variance and skewness have a statistically significant response to a negative shock in the Fed funds rate (expansionary monetary policy) with the responses of the risk neutral skewness being more instant and significantly negative compared to those of the risk neutral variance.

We also estimate a multivariate VAR model in which we control for the business cycles. More specifically, our VAR ordering is the following:

$$
Z_{t}=\left[F F R_{t} I P I_{t} I V_{t} I S_{t}\right]
$$


We continue to place macroeconomic variables first and commodity market variables last in our VAR ordering selection due to the more sluggish response of the former compared to the latter ones. FFR is again the Fed funds rate, IPI is the growth in industrial production index, $I V$ is the implied variance and $I S$ is the implied skewness. We choose our lag-length in each of our multivariate VAR models using again the Akaike criterion. According to the Akaike criterion, the 4-factor VAR for maize has 13 lags, the VAR model for wheat has 6 lags and the model for the soybeans has 4 lags. Our multivariable reduced-form VAR model is the following:

$$
Z_{t}=\delta_{0}+K Z_{t-1}+D \varepsilon_{t}
$$

Where $K$ denotes $B^{-1} A$ and $D$ denotes $A^{-1}$ ( $A$ is the short-run feedback matrix of the structural VAR, according to equations (11) and (12)).

We base again our analysis on the structural form IRFs for the multivariable 4-factor reduced form VAR models for which we estimate the Bootstrapped standard errors using 1000 repetitions. Table 6 reports the months for which the IRFs between the monetary policy (Fed funds rate) and the option-implied expectations are statistically significant.

[Insert Table 6 here]

From Table 6 we see that our results remain robust to the inclusion of business cycles variables since implied skewness and variance respond instantly to monetary policy shocks with the responses being statistically significant. In more detail, we can see that the option-implied skewness responds instantly (after 4-5 months in all commodity markets under investigation) to an expansionary monetary policy shock. Table 4 also 
shows that in all markets considered there is some sluggish response of monetary policy to implied variance shocks. We do not find any statistically significant responses of monetary policy to shocks-sudden shifts in the expectations of commodity investors embedded in implied skewness. This fact strengthens furthermore our initial claims according to which the monetary authority (unlike what it does in times of stock-market turbulence-see Ribobon and Sack (2003)) does not show any intention to manage the expectations in these markets.

Lastly, we examine the dynamic interactions between monetary policy and commodity investors' expectations about extreme (tail) risk in agricultural commodity prices. In order to quantify the investors' expectations about tail risk we compute the kurtosis of the risk neutral distribution of agricultural commodity markets. In order to examine the dynamic interactions between investors' crash-o-phobia and monetary policy, we estimate a bivariate SVAR model of the form which is described in equations (16) to (19), in which we include the Fed funds rate and the option-implied risk neutral kurtosis (IK) as endogenous variables. We base again our analysis on the Impulse Response Functions (IRFs) which are statistically significant. Table 7 reports the relevant results.

[Insert Table 7 here]

The results of table 7 show that the risk neutral kurtosis (unlike the risk neutral variance and skewness) has a sluggish and negative response to negative shocks in the Fed funds rate. More specifically, we find that the risk neutral kurtosis (IK) of maize and soybeans markets has a sluggish and negative response in the SVAR model with the short-run restriction and a positive response in the SVAR model with the long-run 
restriction. In general, the sluggish and opposite reaction of risk neutral kurtosis of agricultural markets to shocks in the Fed funds rate leads us the conclusion that commodity investors' expectations about tail risk are not being significantly affected by shifts in monetary policy.

\subsection{Forecasting monetary policy with option-implied moments}

In this section we examine the predictive power of option-implied expectations on monetary policy. We provide empirical evidence showing that option-implied variance and skewness of maize, wheat and soybeans markets are robust predictors of the monetary policy stance. Table 8 shows the results of our predictive regressions when we regress the Fed funds rate on lagged values of option-implied variance and skewness, with the forecasting horizon ranging from 1 month up to 24 months ahead. Table 9 shows the results of our predictive regressions when we use implied variance and skewness and control for macroeconomic and stock-market factors in order to forecast the monthly Fed funds rate.

[Insert Table 8 Here]

[Insert Table 9 Here]

From Tables 8 and 9 we see that implied variance and skewness are robust predictors of the monetary policy stance. Implied skewness and implied variance have the highest predicative power in the wheat market with an $\mathrm{R}^{2}=45 \%$ for a 6 -month forecasting horizon. For the 6-month forecasting horizon in the soybeans market the $\mathrm{R}^{2}=36 \%$ and in the maize market the $\mathrm{R}^{2}=29 \%$. Even when we control for macroeconomic fundamentals like the inflation rate and the term spread (slope of the 
yield curve) the statistical results remain robust. We find $\mathrm{R}^{2}$ values as high as $45 \%$ (6month forecasting horizon) when we regress wheat implied variance and skewness on the Fed funds rate. The $\mathrm{R}^{2}$ values remain high when we use maize or soybeans implied variance and skewness as predictors of the Fed fund rate. Implied variance and skewness coefficients are all negative and statistically significant. These results are in line with those of David and Veronesi (2014) who find that in equity markets, the put/call ratio (a variable which also measures the degree of bullishness in option markets) of At-The-Money (ATM) index options has a sustained impact and a robust forecasting power on future monetary policy, since it can forecast the path of the short-term US-Treasury Bill for up to eight quarters. Our results may look alike with those of David and Veronesi (2014), but this happens for structurally different reasons. While the Fed systematically reacts to "periods of high VIX levels" (Bekaert, Hoerova and Lo Duca (2013)), we neither find (in the relevant literature) nor provide empirical evidence showing the same for commodity markets. In contrast, our empirical analysis shows that the Fed does not react systematically to periods of increased uncertainty and bullishness in commodity markets and that the implied skewness (bullishness) does not Granger cause the Fed funds rate. This is why we strongly support that our predictive regressions do not suffer from endogeneity ${ }^{18}$ problems: because the information from the commodity derivative market is not taken into consideration by

\footnotetext{
${ }^{18}$ With the term endogeneity, we do not refer to the endogeneity problem in the pure econometric point of view, since we cannot have pure bidirectional causality in forecasting regressions between current (dependent) and lagged (independent) variables. We are referring to the absence of a causal relationship between our predictors of the Fed funds rate and of the Fed funds rate subsequently observed. When for example the inflation level rises, then the US monetary authority raises the Fed funds rate (contractionary policy) as a response in order to control these inflationary pressures. This does not mean that the inflation level can be used as indicator of monetary policy since its 'predictive' power lies in the causal relationship between current inflation and the future policy actions which are used to control it. This 'partial' endogeneity problem is absent from our forecasting models. Our option-implied predictors of the monetary policy stance do not cause the change of the Fed funds rate since the monetary authority does not respond (at least for the time-being) to changes in the option-implied uncertainty and risk aversion of commodity markets.
} 
central banks. ${ }^{19}$ The high adjusted $\mathrm{R}^{2}$ values of our forecasting models show that the option-implied expectations of agricultural markets are strongly affected by (and hence successfully signal and anticipate) the future state of the Fed funds rate and of other measures of monetary policy stance like expected inflation. The increased impact-significance of monetary shocks on the expectations in commodity markets is the key factor behind their tremendous forecasting ability on monetary policy and not any other kind of structural relationship (feedback loop) between monetary policy and commodity markets. This means that the information embedded in the commodity derivative market is useful for predicting the future short-term level of the monetary policy stance.

In addition, the regression results of Table 8 show that option-implied moments are robust predictors of monetary policy for both short and long-term forecasting horizons. For example, we get statistically significant coefficients of the lagged option-implied variance and skewness even when we forecast monetary policy 12 and 24 months ahead, with the $\mathrm{R}^{2}$ values remaining as high as those of the short-term horizon forecasting regressions. When for example we forecast the monetary policy using maize option-implied variance and skewness, we find that $\mathrm{R}^{2}$ values range from $26.9 \%$ (when we forecast the monetary policy 1 month ahead) to $20 \%$ (when we forecast the monetary policy 24 months ahead). This means that the forecasting power of commodity option-markets only slightly deteriorates when we decide to lengthen the forecasting horizon. In other words, we empirically verify that commodity option markets correctly anticipate and, according to Woodford (1994) they are valuable

19 Woodford (1994) supports the view that the indicators of monetary policy which enter in a statistically significant way into predictive regressions are not so significant after all, if they have already become a policy objective. In case an economic or financial variable is not a systematic policy target of monetary authorities and enters significantly into forecasting regressions of the monetary policy stance (like the Fed funds rate), then it can act as a monetary policy indicator. 
"non-standard indicators" of the monetary policy stance since they enter significantly into all of our forecasting regression models. The long-run forecasting power of the option-implied expectations of commodity markets on monetary policy is closely in line with the recent empirical findings of Fernandez-Perez, Fuertes, and Miffre (2016) according to which the expectations for commodity futures prices (being quantified by backwardation and contango commodity market portfolios) are significant indicators of economic activity and for changes in investment opportunities especially for longterm forecasting horizons.

Furthermore, in order to check for the robustness of the goodness-of-fit of our forecasting regression models, we make out-of-sample forecasts for the period $t+h$ (where $h$ is the forecasting horizon) using available data up to month $t$. We use an initial time series window of 60 months and run the regression in order to forecast the $t+h$ Fed funds rate. The estimation window is then extended by one monthly period in order to obtain a new out-of-sample forecast. We run the same forecasting regression models described in tables 8 and 9 in which we make dynamic out-of-sample forecasts and compute the respective out-of-sample $\mathrm{R}^{2}$ values. The out-of-sample $\mathrm{R}^{2}$ values are given in the table 10 below.

\section{[Insert Table 10 Here]}

Our out-of-sample forecasting evidence shows that the predictive power of the risk neutral moments remains practically unaffected for the short and medium-term forecasting horizon (for one up to six months ahead). For example, when using the wheat implied variance (IV) and implied skewness (IS) as predictors of the Fed funds 
rate in our out-of-sample forecasts, we get adjusted $\mathrm{R}^{2}$ of $40.8 \%, 32.6 \%$ and $21.7 \%$ for the one month, three month and six month forecasting horizon respectively, versus $44.6 \%, 43.8 \%$ and $45 \%$ of the respective in-sample adjusted $\mathrm{R}^{2}$ values. On the other hand, the out-of-sample forecasting power of our option-implied risk measures significantly deteriorates for long-term forecasting horizons.

\section{Robustness}

\subsection{Robustness in SVAR modeling}

In this section we conduct a series of robustness tests to test further the validity of the results presented in the previous sections. Our robustness checks along with the relevant results can be found in our Appendix. More specifically, in section A of our Appendix we present the results of our SVAR models when we use some alternative measures (proxies) for the monetary policy stance like the 3-month US Treasury Bill rate, the short-term real interest rate and the state of short-term inflation expectations. We show that when using these alternative widely accepted measures of monetary policy in our SVAR analysis, our empirical results and findings are unaltered. In section B of the Appendix, we provide the results of our SVAR analysis when using the pre-2008 period (the 1990-2007) period as our time series data sample. By this way, we implicitly control for the increased persistence of the Fed funds rate in the post-2008 period during which the Fed funds rate reached and stayed close to its zero lower bound. Again, our results do not differentiate when the increased persistence of the Fed fund rate process is removed from our SVAR analysis. In section C we follow the empirical approach of Bekaert, Hoerova and Lo Duca (2013) and estimate a 5factor VAR model in which we decompose the risk neutral variance into economic uncertainty and risk aversion. Our results indicate that the risk aversion and not the 
uncertainty component of the risk neutral variance is the one which has the more instant and significant response to monetary policy shocks.

\subsection{Robustness in the forecasting regression models}

We additionally provide robustness to the results of our OLS forecasting regression models on monetary policy. More specifically, in section D of the Appendix we run the regression models which are presented in section 3.4 using alternative measures of the monetary policy stance and show that the forecasting power of the option-implied moments on monetary policy remains robust to the inclusion of alternative monetary policy measures. In section E we control for the persistence of the Fed funds rate and in sections F we run our forecasting models during normal (1990-2007) and during the zero lower bound (post-2008) period. In all these alternative estimations of our forecasting models, the coefficients of the risk neutral moments remain negative and statistically significant. These results provide robustness to our initial findings, since we show that the risk neutral expectations of agricultural commodity markets give statistically significant and reliable forecasts for the monetary policy stance irrespective of the increased persistence and of the zero-lower bound of short-term US interest rate environment. Lastly, in section $\mathrm{G}$ of the Appendix we empirically show the absence of significant seasonalities in the agricultural risk neutral moments. This result provides further robustness to our empirical findings, since we show that the time variation of the agricultural risk neutral moments is not being driven by seasonal factors but, probably, by macroeconomic (monetary) factors instead. 


\section{Conclusions}

In this paper we examine the dynamic links between option-implied expectations in agricultural commodity markets and monetary policy. We find that a lax monetary policy has a significant positive effect in implied variance and implied skewness in the maize, wheat and soybeans derivative markets. The impact of monetary shocks on implied skewness is much greater compared to the impact on implied variance. Our empirical results are in sharp contrast to those obtained by Bernanke and Kuttner (2005) and Bekaert, Hoerova and Lo Duca (2013) who find that an expansionary monetary policy reduces uncertainty in equity markets. Commodity investors revise upwards their expectations about volatility risk after observing a negative interest rate shock (expansionary policy), while equity investors revise downwards their expectations about volatility risk after observing the same shock. Our empirical findings are the first to show the opposite reaction of the expectations in agricultural commodity markets (compared to the reaction of the stock-market) to monetary policy shocks. The reactions of the option-implied expectations in agricultural markets are quite similar in terms of timing and magnitude. The policy implication behind this empirical results is that the monetary policy-maker (when lowering the interest rates) faces a trade-off between calming down the uncertainty and risk aversion in equity and agricultural commodity markets. The impact of monetary shocks to the risk aversion and to expectations in the rest commodity markets (e.g. the mineral and the energy commodity markets) remains unknown and is a fruitful area for further research. In addition, while we show that the option-implied kurtosis does not systematically respond to monetary policy shocks, we leave for further research the examination of dynamic interactions between monetary policy and other tail risk measures which quantify commodity investors' perceptions about jump tail risk. We also provide 
empirical evidence showing the robust forecasting power of implied variance and skewness on monetary policy with $\mathrm{R}^{2}$ values reaching almost $52 \%$. Following Woodford (1994), these option-implied moments could be used as "non-standard indicators" of the monetary policy stance. Consequently, we leave the empirical examination of the forecasting power of the option-implied risk neutral moments of the rest commodity markets as a topic for further research. 


\section{References}

Andrian, T., and H.S., Shin. (2008). "Liquidity, Monetary Policy and Financial Cycles." Current Issues in Economics and Finance 14 (1), Federal Reserve Bank of New York

Angeloni, I., Faia, E., and M., Lo Duca (2015). "Bank Risk Taking and Monetary Policy". Journal of Economic Dynamics and Control, 52, 285-307

Anzuini, A., M.J., Lombardi, and P., Pagano. (2013). "The Impact of Monetary Policy Shocks on Commodity Prices." International Journal of Central Banking 9 (3), 125-150

Awokuse, T.O., and J., Yang. (2003). "The informational role of commodity prices in formulating monetary policy: A reexamination.” Economics Letters 79, 219-224

Bakshi, G., Kapadia, N., and D., Madan. (2003). "Stock Return Characteristics, Skew Laws, and the Differential Pricing of Individual Equity Options." Review of Financial Studies $16(1), 101-143$

Barndorff-Nielsen, O.E., and N., Sheppard. (2002). "Estimating quadratic variation using realized variance." Journal of Applied Econometrics, 17(5), 457-477

Barro, R.J. (1977). "Unanticipated Money Growth and Unemployment in the United States.” American Economic Review 67, 101-115

Barro, R.J. (1978). "Unanticipated Money, Output, and the Price Level in the United States." Journal of Political Economy 86, 547-580

Bekaert, G., Hoerova, M., and M., Lo Duca. (2013). "Risk, Uncertainty and Monetary Policy.” Journal of Monetary Economics 60 (7), 771-788

Bernanke, B.S., and I., Mihov. (1998). "The Liquidity Effect and Long-Run Neutrality.” Carnegie Rochester Conference Series on Public Policy 49 (1), 149-194

Bernanke, B.S., and M., Gertler. (1999). "Monetary Policy and Asset Price Volatility." In New Challenges for Monetary Policy: A Symposium Sponsored by the Federal Reserve Bank of Kansas City. Federal Reserve Bank of Kansas City, 77-128

Bernanke, B.S., and M., Gertler. (2001). "Should Central Banks Respond to Movements in Asset Prices?" American Economic Review 91 (2), 253-257

Bernanke, B.S., and K.N., Kuttner. (2005). "What Explains the Stock Market's Reaction to Federal Reserve Policy?” Journal of Finance 60 (3), 253-257

Bernanke, B.S. (2007). "Inflation Expectations and Inflation Forecasting." Speech at the Monetary Economics Workshop of the National Bureau of Economic Research Summer Institute, Cambridge, Massachusetts July 10, 2007

Bessler, D.A. (1984). "Relative prices and money: a vector autoregression on Brazilian data." American Journal of Agricultural Economics 66, 25-30

Bhar, R., and S., Hamori. (2008). "Information content of commodity futures prices for monetary policy." Economic Modeling 25, 274-283 
Black, F. (1976). "The Pricing of Commodity Contracts.” Journal of Financial Economics $3,167-179$

Blanchard, O.J., and D., Quah. (1989). "The Dynamic Effects of Aggregate Demand and Supply Disturbances.” American Economic Review 79, 1146-1164

Bliss, R.R., and N., Panigirtzoglou. (2004). “Option-Implied Risk Aversion Estimates.” Journal of Finance 59 (1), 407-446

Borio, C., and P.W., Lowe. (2002). "Asset Prices, Financial and Monetary Stability: Exploring the Nexus.” BIS Working Paper No.114

Borio, C., and H., Zhu. (2012). "Capital Regulation, Risk Taking and Monetary Policy: A Missing Link in the Transmission Mechanism?” Journal of Financial Stability 8 (4), 236-251

Bordo, M. (1980). The Effects of Monetary Change on Relative Commodity Prices and the Role of Long-Term Contracts. Journal of Political Economy, 88, 1088-1109

Brennan, M.J. (1958). The supply of storage. American Economic Review 48, 50-72

Bruno, V., and H.S., Shin (2015). "Capital Flows and the Risk Taking Channel of Monetary Policy". Journal of Monetary Economics, 71, 119-132

Calvo, G. (2008). "Exploding Commodity Prices, lax monetary policy and sovereign wealth funds." VoxEU 20 June 2008

Carr, P., and L., Wu (2009). "Variance Risk Premiums." Review of Financial Studies 22 (3), 1311-1341

Chang B-Y, P., Christoffersen, Jacobs, K., and G., Vainberg. (2012). "Option-Implied Measures of Equity Risk.” Review of Finance 16, 385-428

Chambers, R.G., and R.E., Just (1992). An investigation of the effect of monetary factors in agriculture. Journal of Monetary Economics, 9(2), 235-247

Christie, A.A. (1982). The Stochastic Behavior of Common-Stock Variances - Value, Leverage and Interest Rate Effects. Journal of Financial Economics, 31, 281-318

Cody, Brian J., and Leonard O. Mills. (1991). "The role of commodity prices in formulating monetary policy." Review of Economics and Statistics 78, 16-34

Daskalaki, C., Kostakis, A., and G., Skiadopoulos. (2014). Are There Common Factors in individual commodity futures returns? Journal of Banking and Finance 40, 346-363

David, A., and P., Veronesi. (2014). "Investor and Central Bank Uncertainty Embedded in Index Options.” Review of Financial Studies 27 (6), 1661-1716

Deaton, A., and G., Laroque. (1992). On the Behavior of Commodity Prices. Review of Economic Studies 59(1), 1-23

Doran, J.S., and E.I., Ronn (2008). Computing the Market Price of Volatility Risk in the Energy Commodity Markets. Journal of Banking and Finance, 32(12), 2541-2552

Dornbusch, R. (1976). Expectations and exchange rate dynamics. Journal of Political Economy, 84, 1161-1176 
Fama, E.F, and K.R., French (1987). Commodity Futures Prices: Some Evidence on Forecast Power, Premiums and the Theory of Storage. Journal of Business 60, 55-73

Fernandez-Perez, A., Fuertes, A-M., and J. Miffre. (2016). Commodity markets, long-term predictability and intertemporal pricing. Review of Finance, rfw034

Frankel, J.A. (1986). "Expectations and Commodity Price Dynamics: The Overshooting Model." American Journal of Agricultural Economics 68(2), 344-348

Frankel, J.A. (2008). "The Effect of Monetary Policy on Real Commodity Prices” in J. Y. Campbell: Asset Prices and Monetary Policy, pp. 291-333. University of Chicago Press.

Frankel, J.A. (2013). "Effects of Speculation and Interest Rates in a 'Carry Trade' Model of Commodity Prices." Written for Understanding International Commodity Price Fluctuations, an International Conference organized by the IMF and Oxford University

Frankel, J.A., and G.A., Hardouvelis. (1985). "Commodity Prices, Money Surprises and Fed Credibility.” Journal of Money, Credit and Banking 17 (4), 425-438

Frankel, J.A., and A.K., Rose. (2010). "Determinants of Agricultural and Mineral Commodity Prices” In Inflation in an era of Relative Price Shocks. Reserve Bank of Australia. Garner, C.A. (1989). “Commodity Prices: Policy Target or Information Variable?: Note.” Journal of Money Credit and Banking 21(4), 508-514

Gilbert, C.L. (2010). "How to Understand High Food Prices" Journal of Agricultural Economics 61(2), 398-425

Gordon, G., and K.G., Rouwenhorst. (2006). "Facts and Fantasies about Commodity Futures." Financial Analysts Journal 62, 47-68

Gordon, G.B., Hayashi, F., and Rowenhorst, K.G. (2013). The Fundamentals of Commodity Futures Returns. Review of Finance 17, 35-105

Gospodinov, N., and Ng, S. (2013). "Commodity Prices, Convenience Yields and Inflation.” Review of Economics and Statistics 95 (1), 206-219

Gospodinov, N., and I., Jamali. (2013). "Monetary Policy Surprises, Positions of Traders, and Changes in Commodity Futures Prices.” FRB-Atlanta Working Paper 2013-12

Gubler, M., and M.S., Hertweck. (2013). "Commodity price shocks and the business cycle: Structural evidence from the US." Journal of International Money and Finance 37, 324-352

Hammoudeh, S., D.K., Nguyen, and R.M., Sousa (2015). "US Monetary Policy and Sectoral Commodity Prices.” Journal of International Money and Finance 57, 61-85

Han, B. (2008). "Investor Sentiment and Option Prices." Review of Financial Studies 21(1), 387-414

Hua, P. (1998). "On primary commodity prices: the impact of macroeconomic/monetary shocks." Journal of Policy Modeling 20, 767-790

Jiang, G.J., and Y.S., Tian. (2005). "The Model-Free Implied Volatility and Its Information Content.” Review of Financial Studies 18(4), 1305-1342 
Jimenez, G., Ongena, S., Peydro, J-L., and J. Saurina (2014). Hazardous Times for Monetary Policy: What Do Twenty-Three Million Bank Loans Say about the Effects of Monetary Policy on Credit Risk-Taking? Econometrica 82(2), 463-505

Kaldor, N. (1939). Speculation and Economic Stability. Review of Economic Studies 7, 127

Lucas, R.E. (1972). "Expectations and the Neutrality of Money." Journal of Economic Theory 4, 103-124

Lucas, R.E. (1976). "Econometric Policy Evaluation: A Critique.” Carnegie-Rochester Series on Public Policy 1, 19-46

Mishkin, F.S., and E.N., White. (2002). "US-Stock Market Crashes and Their Aftermath: Implications for Monetary Policy.” NBER Working Paper No.8992

Newey, W.K., and K.D., West. (1987). "A Simple, Positive, Semi-definite Heteroscedasticity and Autocorrelation Consistent Covariance Matrix.” Econometrica 55, $703-$ 708

Okun, A.M. (1975). Inflation: Its Mechanics and Welfare Costs. Brookings Papers on Economic Activity, 2, 451-401

Prokopczuk, M., and C.W. Simen (2014). Variance Risk Premia in Commodity Markets. Available at SSRN: http://ssrn.com/abstract=2195691

Pindyck, R.S., and J.J., Rotemberg. (1990). "The excess co-movement of commodity prices.” Economic Journal 100, 1173-1189

Rajan, R.G. (2006). "Has Finance Made the World Riskier?" European Financial Management 12(4), 499-533

Rehman Z., and G., Vilkov. (2012). "Risk Neutral Skewness: Return predictability and its sources." SSRN March 13, 2012

Rigobon, R., and B., Sack. (2003). "Measuring the Reaction of Monetary Policy to the Stock Market.” Quarterly Journal of Economics 118 (2), 639-669

Robertson. J.C., and D., Orden (1990). Monetary Impacts on Prices in the Short and Long Run: Some Evidence from New Zealand, American Journal of Agricultural Economics, 72(1), 160-171

Saghaian, S.H., Reed, M.R., and M.A., Marchant (2002). Monetary Impacts and Overshooting of Agricultural Prices in an Open Economy. American Journal of Agricultural Economics, 84(1), 90-103

Simon, D.P. (2003). Implied Volatility Forecasts in the Grains Complex. Journal of Futures Markets, 22(10), 959-981

Telser, L.G. (1958). Futures trading and the storage of cotton and wheat. Journal of Political Economy 66, 233-255 
Trolle, A.B., and E.S., Schwartz (2010). Variance Risk Premia in Energy Commodities. Journal of Derivatives, Spring 2010, 17(3), 15-32

Wang, Z., Fausti, S.W., and B.A., Qasmi. (2012). "Variance Risk Premiums and Predictive Power of Alternative Forward Variances in the Corn Market.” Journal of Futures Markets 32 (6), 587-608

Woodford, M. (1994). "Non-standard indicators for Monetary Policy: Can Their Usefulness be judged from Forecasting Regressions?" In N. Gregory Mankiw: Monetary Policy, pp.95-115. The University of Chicago Press.

Working, H. (1948). Theory of the inverse carrying charge in futures markets. Journal of Farm Economics 30, 1-28

Working, H. (1949). The theory of price of storage. American Economic Review 39, $1254-1262$ 
Table 1: Maize-Wheat-Soybeans Descriptive Statistics

This table shows descriptive statistics of Realized Variance (RV), Implied Variance (IV) and Implied Skewness (IS). The data have a monthly frequency. The table presents also the Augmented DickeyFuller (ADF) and the Philips-Perron (PP) test statistics for each one of the variables. In each test the null hypothesis is that the time series variable has a unit root. Lags in ADF tests are chosen by the Swartz information criterion. The sample period for maize, wheat and soybeans data is from January 1990 to December 2011.

\begin{tabular}{|c|c|c|c|}
\hline \multicolumn{4}{|c|}{ Maize } \\
\hline & $\mathrm{RV}$ & IV & IS \\
\hline Mean & 0.064 & 0.069 & -0.104 \\
\hline Median & 0.043 & 0.054 & 0.065 \\
\hline Maximum & 0.365 & 0.237 & 1.071 \\
\hline Minimum & 0.004 & 0.015 & -2.214 \\
\hline Stand. Dev & 0.058 & 0.044 & 0.632 \\
\hline Skewness & 2.410 & 1.260 & -1.206 \\
\hline Kurtosis & 10.937 & 4.569 & 4.086 \\
\hline ADF test & -5.933 & -4.677 & -2.091 \\
\hline PP test & -10.410 & -6.131 & -8.748 \\
\hline \multicolumn{4}{|c|}{ Wheat } \\
\hline & $\mathrm{RV}$ & IV & IS \\
\hline Mean & 0.075 & 0.073 & 0.018 \\
\hline Median & 0.059 & 0.057 & 0.091 \\
\hline Maximum & 0.324 & 0.348 & 0.820 \\
\hline Minimum & 0.008 & 0.014 & -2.305 \\
\hline Stand. Dev & 0.057 & 0.051 & 0.423 \\
\hline Skewness & 1.887 & 2.117 & -1.957 \\
\hline Kurtosis & 6.963 & 9.098 & 10.135 \\
\hline ADF test & -2.965 & -1.985 & -3.222 \\
\hline PP test & -9.063 & -4.870 & -8.405 \\
\hline \multicolumn{4}{|c|}{ Soybeans } \\
\hline & $\mathrm{RV}$ & IV & IS \\
\hline Mean & 0.053 & 0.069 & 0.029 \\
\hline Median & 0.037 & 0.048 & 0.124 \\
\hline Maximum & 0.277 & 0.403 & 1.299 \\
\hline Minimum & 0.003 & 0.011 & -2.53 \\
\hline Stand. Dev & 0.047 & 0.060 & 0.615 \\
\hline Skewness & 2.334 & 2.639 & -1.431 \\
\hline Kurtosis & 9.1480 & 12.488 & 6.2581 \\
\hline $\mathrm{ADF}$ test & -6.335 & -2.820 & -6.638 \\
\hline PP test & -8.726 & -7.721 & -8.242 \\
\hline
\end{tabular}


Table 2: Correlation matrix for option-implied moments

This table shows the correlation matrix with the respective correlation coefficients between the optionimplied risk neutral variance and skewness of maize, wheat and soybeans markets. The sample period for maize, wheat and soybeans data is from January 1990 to December 2011.

\begin{tabular}{|c|c|c|c|c|c|c|}
\hline & Maize IV & Wheat IV & Soybeans IV & Maize IS & Wheat IS & Soybeans IS \\
\hline Maize IV & 1.00 & & & & & \\
\hline Wheat IV & 0.77 & 1.00 & & & & \\
\hline Soybeans IV & 0.78 & 0.82 & 1.00 & & & \\
\hline Maize IS & 0.41 & 0.27 & 0.29 & 1.00 & & \\
\hline Wheat IS & 0.34 & 0.34 & 0.29 & 0.65 & 1.00 & \\
\hline Soybeans IS & 0.36 & 0.22 & 0.20 & 0.63 & 0.49 & 1.00 \\
\hline
\end{tabular}


Table 3: Granger causality tests between monetary policy and option-implied moments This table shows the results of the Granger causality tests between monetary policy and option-implied variance and skewness of commodity markets under investigation. The tests refer to the bivariate VAR models which include the Fed funds rate and option-implied variance and the Fed funds rate and optionimplied skewness ([FFR IV], [FFR IS]). The optimal lag-length in these bivariate VAR models has been chosen using the Akaike criterion. The null hypothesis is that the Independent variable does not Granger cause the Dependent variable. With $*, * *$ and $* * *$ we reject the null hypothesis of no causality at the $10 \%, 5 \%$ and $1 \%$ level respectively.

\begin{tabular}{llcc}
\hline \hline Dependent variable & Independent variable & chi-square & p-value \\
\hline \hline Fed funds rate** & Maize implied variance & 22.37 & 0.033 \\
Fed funds rate*** & Wheat implied variance & 23.06 & 0.002 \\
Fed funds rate** & Soybeans implied variance & 12.56 & 0.013 \\
Fed funds rate & Maize implied skewness & 11.47 & 0.488 \\
Fed funds rate & Wheat implied skewness & 14.99 & 0.183 \\
Fed funds rate & Soybeans implied skewness & 5.05 & 0.653 \\
Maize implied variance*** & Fed funds rate & 30.31 & 0.002 \\
Wheat implied variance & Fed funds rate & 9.95 & 0.191 \\
Soybeans implied variance & Fed funds rate & 5.14 & 0.273 \\
Maize implied skewness* & Fed funds rate & 19.46 & 0.078 \\
Wheat implied skewness*** & Fed funds rate & 27.07 & 0.005 \\
Soybeans implied skewness*** & Fed funds rate & 29.93 & 0.0001 \\
\hline \hline
\end{tabular}


Table 4. Statistical significance of IRFs between monetary policy and implied variance/implied skewness (bivariate SVAR model)

This table summarizes the results of bivariate structural and reduced-form VARs with endogenous variables the Fed funds rate (FFR) and the risk neutral implied variance (IV) in Panel A and the Fed funds rate (FFR) and implied skewness (IS) in Panel B. We present how many months the Impulse Response Functions (IRFs) generated by a negative shock in FFR or a positive shock in IV/IS remain statistically significant within the $95 \%$ confidence interval. We compute the Bootstrapped standard errors of the estimated IRFs using 1000 replications. The column "sign" indicates the sign of the statistically significant IRFs.

Panel A

\begin{tabular}{|c|c|c|c|c|}
\hline & \multicolumn{2}{|c|}{ Impulse MP, response Maize IV } & \multicolumn{2}{|c|}{ Impulse Maize IV, response MP } \\
\hline & sign & significant from-to (month) & sign & significant from-to (month) \\
\hline \multicolumn{5}{|l|}{ Fed Fund Rate } \\
\hline -reduced-form & + & $8-25$ & - & $30-42$ \\
\hline -structural short-run & + & $7,8-10$ & & -- \\
\hline \multirow[t]{3}{*}{-structural long-run } & + & $3,7-8,10-25$ & - & $38-58$ \\
\hline & \multicolumn{2}{|c|}{ Impulse MP, response Wheat IV } & \multicolumn{2}{|c|}{ Impulse Wheat IV, response MP } \\
\hline & sign & significant from-to (month) & sign & significant from-to (month) \\
\hline \multicolumn{5}{|l|}{ Fed Fund Rate } \\
\hline -reduced-form & + & $1-3$ & - & $20-41$ \\
\hline -structural short-run & + & 1,3 & & -- \\
\hline \multirow[t]{3}{*}{-structural long-run } & + & 3 & - & $19-44$ \\
\hline & \multicolumn{2}{|c|}{ Impulse MP, response Soybeans IV } & \multicolumn{2}{|c|}{ Impulse Soybeans IV, response MP } \\
\hline & sign & significant from-to (month) & sign & significant from-to (month) \\
\hline \multicolumn{5}{|l|}{ Fed Fund Rate } \\
\hline -reduced form & + & $4-15$ & & $9-21$ \\
\hline -structural short-run & + & $4-5,7-14$ & & -- \\
\hline -structural long-run & + & -- & - & 4-39 \\
\hline \multicolumn{5}{|c|}{ Panel B } \\
\hline & \multicolumn{2}{|c|}{ Impulse MP, response Maize IS } & \multicolumn{2}{|c|}{ Impulse Maize IS, response MP } \\
\hline & sign & significant from-to (month) & sign & significant from-to (month) \\
\hline \multicolumn{5}{|l|}{ Fed Fund Rate } \\
\hline -reduced-form & + & $6-35$ & & -- \\
\hline -structural short-run & + & $7,10,19-23$ & & -- \\
\hline \multirow[t]{3}{*}{-structural long-run } & + & $7,10,18-22$ & & -- \\
\hline & \multicolumn{2}{|c|}{ Impulse MP, response Wheat IS } & \multicolumn{2}{|c|}{ Impulse Wheat IS, response MP } \\
\hline & sign & significant from-to (month) & sign & significant from-to (month) \\
\hline \multicolumn{5}{|l|}{ Fed Fund Rate } \\
\hline -reduced-form & + & $4-40$ & & -- \\
\hline -structural short-run & + & $2-5,7,9-28$ & + & $2-3$ \\
\hline \multirow[t]{3}{*}{-structural long-run } & + & $20-25$ & & -- \\
\hline & \multicolumn{2}{|c|}{ Impulse MP, response Soybeans IS } & \multicolumn{2}{|c|}{ Impulse Soybeans IS, response MP } \\
\hline & sign & significant from-to (month) & sign & significant from-to (month) \\
\hline \multicolumn{5}{|l|}{ Fed Fund Rate } \\
\hline -reduced-form & + & $8-33$ & & -- \\
\hline -structural short-run & + & $6-32$ & & -- \\
\hline -structural long-run & + & $6-10,18-34$ & - & $1-31$ \\
\hline
\end{tabular}


Table 5. Statistical significance of IRFs between monetary policy and implied variance/implied skewness (3-factor SVAR model)

This table summarizes the results of 3-factor SVAR model with endogenous variables the Fed funds rate (FFR), the risk neutral variance (IV) and the risk neutral skewness (IS). We present how many months the IRFs generated by a negative shock in FFR or a positive shock in IV/IS remain statistically significant within the 95\% confidence interval. The IRFs of the IV-FFR and IS-FFR pair are given in Panels A and B respectively. We compute the Bootstrapped standard errors of the estimated IRFs using 1000 replications. The column "sign" indicates the sign of the statistically significant IRFs.

Panel A

\begin{tabular}{|c|c|c|c|c|}
\hline & \multicolumn{2}{|c|}{ Impulse MP, response Maize IV } & \multicolumn{2}{|c|}{ Impulse Maize IV, response MP } \\
\hline & sign & significant from-to (month) & sign & significant from-to (month) \\
\hline \multicolumn{5}{|l|}{ Fed Fund Rate } \\
\hline -reduced-form & + & $3,9-10,12$ & + & $2-3$ \\
\hline -structural short-run & + & $3,7,9-10,21$ & & - \\
\hline \multirow[t]{3}{*}{-structural long-run } & + & $3,7,9-10,18-19,21$ & & $\underline{-}$ \\
\hline & \multicolumn{2}{|c|}{ Impulse MP, response Wheat IV } & \multicolumn{2}{|c|}{ Impulse Wheat IV, response MP } \\
\hline & sign & significant from-to (month) & sign & significant from-to (month) \\
\hline \multirow{6}{*}{$\begin{array}{l}\text { Fed Fund Rate } \\
\text {-reduced-form } \\
\text {-structural short-run } \\
\text {-structural long-run }\end{array}$} & \multirow{4}{*}{+} & & & \\
\hline & & $1,4-14$ & - & $1,16-32$ \\
\hline & & $2,4-9$ & & - \\
\hline & & - & - & $21-58$ \\
\hline & \multicolumn{2}{|c|}{ Impulse MP, response Soybeans IV } & \multicolumn{2}{|c|}{ Impulse Soybeans IV, response MP } \\
\hline & sign & significant from-to (month) & sign & significant from-to (month) \\
\hline \multicolumn{5}{|l|}{ Fed Fund Rate } \\
\hline -reduced form & + & $8-10,18$ & & - \\
\hline -structural short-run & + & $8-10$ & & - \\
\hline -structural long-run & + & $7-10,18$ & & - \\
\hline \multicolumn{5}{|c|}{$\begin{array}{l}\text { Panel B } \\
\end{array}$} \\
\hline & \multicolumn{2}{|c|}{ Impulse MP, response Maize IS } & \multicolumn{2}{|c|}{ Impulse Maize IS, response MP } \\
\hline & sign & significant from-to (month) & sign & significant from-to (month) \\
\hline \multirow{6}{*}{$\begin{array}{l}\text { Fed Fund Rate } \\
\text {-reduced-form } \\
\text {-structural short-run } \\
\text {-structural long-run }\end{array}$} & & & & \\
\hline & + & $4,7-11,13,18-23,25,33$ & - & $43-57$ \\
\hline & + & $4,7-11,17-23,31-33$ & & - \\
\hline & + & $7,9-11,16,18-22$ & & - \\
\hline & \multicolumn{2}{|c|}{ Impulse MP, response Wheat IS } & \multicolumn{2}{|c|}{ Impulse Wheat IS, response MP } \\
\hline & sign & significant from-to (month) & sign & significant from-to (month) \\
\hline \multirow{6}{*}{$\begin{array}{l}\text { Fed Fund Rate } \\
\text {-reduced-form } \\
\text {-structural short-run } \\
\text {-structural long-run } \\
\end{array}$} & & & & \\
\hline & + & $5-33$ & + & 1 \\
\hline & + & $6-31$ & & - \\
\hline & + & $11-39$ & - & $1-36$ \\
\hline & \multicolumn{2}{|c|}{ Impulse MP, response Soybeans IS } & \multicolumn{2}{|c|}{ Impulse Soybeans IS, response MP } \\
\hline & sign & significant from-to (month) & sign & significant from-to (month) \\
\hline \multicolumn{5}{|l|}{ Fed Fund Rate } \\
\hline -reduced-form & + & $5-7,9,15,18-22$ & & - \\
\hline -structural short-run & + & $5-7,9,15,18-22,30-34$ & & - \\
\hline -structural long-run & + & $5-7,9,18-22,30-34$ & - & $5-34$ \\
\hline
\end{tabular}


Table 6. Statistical significance of IRFs between monetary policy and option-implied expectations of commodity markets (4-factor VAR model)

This table summarizes the results for the IRFs between monetary policy and option-implied expectations when we estimate a 4-factor VAR model presented in section 3.3. These IRFs are estimated for our 4-factor reduced-form VAR models with endogenous variables the monthly level of the Fed funds rate (FFR), the growth of the Industrial Production Index (IPI), the implied variance (IV) and the implied skewness (IS) of maize, wheat and soybeans markets. We present the IRFs of commodity markets to a negative monetary shock and the IRFs of monetary policy to a positive shock in commodity markets. More specifically, we present how many months the Impulse Response Functions (IRFs) remain statistically significant within the $95 \%$ Bootstrapped confidence interval. Thus, we estimate for the three commodity markets a multivariate VAR model of the form: $Y_{1}=[$ FFR IPI IV IS]. We compute the Bootstrapped standard errors of the estimated IRFs using 1000 replications. Panel A shows the results for the IRFs for the implied variance (IV)-monetary policy (Fed funds rate) pair and Panel B shows the results for the IRFs for the implied skewness (IS)-monetary policy (Fed funds rate) pair for maize, wheat and soybeans markets. The column "sign" indicates the sign of the statistically significant IRFs.

Panel A

\begin{tabular}{l|c|c|c|c}
\hline \hline & \multicolumn{2}{|c|}{ Impulse FFR- Response IV } & \multicolumn{2}{c}{ Impulse IV, response FFR } \\
\hline \hline & sign & significant from-to (month) & sign & significant from-to (month) \\
\hline -Maize & + & $7-11$ & - & $29-36$ \\
- Wheat & + & $1-9$ & - & $24-45$ \\
-Soybeans & + & $3-18$ & - & $24-34$ \\
\hline \hline
\end{tabular}

Panel B

\begin{tabular}{l|c|c|c|c}
\hline \hline & \multicolumn{2}{|c|}{ Impulse FFR- Response IS } & \multicolumn{2}{c}{ Impulse IS, response FFR } \\
\hline \hline & sign & significant from-to (month) & sign & significant from-to (month) \\
\hline -Maize & + & $8-11$ & & - \\
-Wheat & + & $4-31$ & & - \\
-Soybeans & + & $5-33$ & & - \\
\hline \hline
\end{tabular}


Table 7. Statistical significance of IRFs between monetary policy and implied kurtosis

This table summarizes the results of bivariate structural and reduced-form VARs with endogenous variables the Fed funds rate (FFR) and the risk neutral implied kurtosis (IK). We present how many months the Impulse Response Functions (IRFs) generated by a negative shock in FFR or a positive shock in IK remain statistically significant within the $95 \%$ confidence interval. We compute the Bootstrapped standard errors of the estimated IRFs using 1000 replications. The column "sign" indicates the sign of the statistically significant IRFs. For the case of the IRF of the risk neutral kurtosis of the maize and soybeans market, we include two lines for the responses of the long-run SVAR model, since it the responses of the risk neutral kurtosis on monetary shocks change sign in a statistically significant manner.

\begin{tabular}{|c|c|c|c|c|}
\hline & \multicolumn{2}{|c|}{ Impulse MP, response Maize IK } & \multicolumn{2}{|c|}{ Impulse Maize IK, response MP } \\
\hline & sign & significant from-to (month) & sign & significant from-to (month) \\
\hline $\begin{array}{l}\text { Fed Fund Rate } \\
\text {-reduced-form } \\
\text {-structural short-run } \\
\text {-structural long-run (-) } \\
\text {-structural long-run (+) }\end{array}$ & $\begin{array}{l}- \\
- \\
- \\
+\end{array}$ & $\begin{array}{c}6-11,18-23,31-34 \\
6-11,13,18-22,31-33 \\
6-10,18-21 \\
1-2,12,14,26 \\
\end{array}$ & + & $\begin{array}{c}36-60 \\
- \\
- \\
26-49 \\
\end{array}$ \\
\hline \multirow{2}{*}{-structural long-run $(+)$} & \multicolumn{2}{|c|}{ Impulse MP, response Wheat IK } & \multicolumn{2}{|c|}{ Impulse Wheat IK, response MP } \\
\hline & sign & significant from-to (month) & sign & significant from-to (month) \\
\hline $\begin{array}{l}\text { Fed Fund Rate } \\
\text {-reduced-form } \\
\text {-structural short-run } \\
\text {-structural long-run }\end{array}$ & $\begin{array}{l}- \\
-\end{array}$ & $\begin{array}{c}7 \\
16-20 \\
- \\
\end{array}$ & + & $\begin{array}{c}39-56 \\
- \\
- \\
\end{array}$ \\
\hline \multirow{2}{*}{-structural long-run } & \multicolumn{2}{|c|}{ Impulse MP, response Soybeans IK } & \multicolumn{2}{|c|}{ Impulse Soybeans IK, response MP } \\
\hline & sign & significant from-to (month) & sign & significant from-to (month) \\
\hline $\begin{array}{l}\text { Fed Fund Rate } \\
\text {-reduced form } \\
\text {-structural short-run } \\
\text {-structural long-run (-) } \\
\text {-structural long-run (+) }\end{array}$ & $\begin{array}{l}- \\
- \\
- \\
+\end{array}$ & $\begin{array}{c}9-11 \\
9-11,21-23,44-45 \\
9 \\
14,24-26 \\
\end{array}$ & + & $\begin{array}{c}36-60 \\
- \\
- \\
34-59 \\
\end{array}$ \\
\hline
\end{tabular}


Table 8: Forecasting monetary policy (Fed funds rate) with option-implied variance and skewness for long and short-term forecasting horizons

This table shows time-series regressions on monthly monetary policy stance (Fed funds rate), using as explanatory variables lagged values of option-implied variance and skewness for maize, wheat and soybeans futures respectively. In Panels A, B, C we run our predictive regressions on the Fed funds rate (FFR) using lagged values of maize, wheat and soybeans option-implied variance and skewness respectively. Our forecasting horizon ranges from 1 to 24 months. IV is option-implied variance, IS option-implied skewness and FFR is the Fed funds rate. The t-statistics reported in the relevant columns are corrected for autocorrelation and heteroscedasticity using the Newey-West (1987) estimator. We forecast the future monetary policy stance $\mathrm{k}$ months ahead $(\mathrm{k}=1,3,6,12,24)$ according to the following regression model:

$$
F F R_{t}=b_{0}+b_{1} I V_{t-k}+b_{2} I S_{t-k}+\varepsilon_{t}
$$

A: Maize

\begin{tabular}{cccccccc}
\hline \hline Horizon $(\mathrm{k})$ & $\mathrm{bo}$ & $\mathrm{t}-\mathrm{stat}\left(\mathrm{b}_{0}\right)$ & $\mathrm{b}_{1}$ & $\mathrm{t}-\operatorname{stat}\left(\mathrm{b}_{1}\right)$ & $\mathrm{b}_{2}$ & $\mathrm{t}-\mathrm{stat}\left(\mathrm{b}_{2}\right)$ & $\%$ Adj. $\mathrm{R}^{2}$ \\
\hline $1 \mathrm{~m}$ & 0.048 & 11.34 & -0.191 & -3.368 & -0.008 & -2.873 & 26.9 \\
$3 \mathrm{~m}$ & 0.048 & 11.33 & -0.193 & -3.717 & -0.008 & -2.699 & 27.4 \\
$6 \mathrm{~m}$ & 0.048 & 11.39 & -0.197 & -3.848 & -0.007 & -2.435 & 29.1 \\
$12 \mathrm{~m}$ & 0.047 & 11.03 & -0.200 & -3.930 & -0.004 & -1.437 & 26.2 \\
$24 \mathrm{~m}$ & 0.048 & 12.02 & -0.240 & -5.016 & -0.0004 & -0.186 & 20.0 \\
\hline \hline
\end{tabular}

B: Wheat

\begin{tabular}{cccccccc}
\hline \hline Horizon $(\mathrm{k})$ & $\mathrm{bo}$ & $\mathrm{t}-\mathrm{stat}\left(\mathrm{b}_{0}\right)$ & $\mathrm{b}_{1}$ & $\mathrm{t}-\mathrm{stat}\left(\mathrm{b}_{1}\right)$ & $\mathrm{b}_{2}$ & $\mathrm{t}$-stat $\left(\mathrm{b}_{2}\right)$ & $\%$ Adj. $\mathrm{R}^{2}$ \\
\hline $1 \mathrm{~m}$ & 0.049 & 14.02 & -0.175 & -4.051 & -0.024 & -6.405 & 44.6 \\
$3 \mathrm{~m}$ & 0.049 & 14.24 & -0.183 & -4.567 & -0.021 & -5.386 & 43.8 \\
$6 \mathrm{~m}$ & 0.050 & 15.58 & -0.202 & -6.509 & -0.018 & -4.565 & 45.0 \\
$12 \mathrm{~m}$ & 0.049 & 14.88 & -0.212 & -7.163 & -0.011 & -2.623 & 39.3 \\
$24 \mathrm{~m}$ & 0.049 & 13.26 & -0.239 & -6.336 & -0.001 & -0.427 & 25.9 \\
\hline \hline
\end{tabular}

C: Soybeans

\begin{tabular}{cccccccc}
\hline \hline Horizon $(\mathrm{k})$ & bo & $\mathrm{t}$-stat $\left(\mathrm{b}_{0}\right)$ & $\mathrm{b}_{1}$ & $\mathrm{t}$-stat $\left(\mathrm{b}_{1}\right)$ & $\mathrm{b}_{2}$ & $\mathrm{t}$-stat $\left(\mathrm{b}_{2}\right)$ & \% Adj. $\mathrm{R}^{2}$ \\
\hline $1 \mathrm{~m}$ & 0.047 & 14.37 & -0.167 & -4.135 & -0.010 & -3.981 & 33.9 \\
$3 \mathrm{~m}$ & 0.047 & 14.77 & -0.173 & -5.261 & -0.010 & -4.313 & 35.1 \\
$6 \mathrm{~m}$ & 0.047 & 15.00 & -0.179 & -6.283 & -0.008 & -3.980 & 36.0 \\
$12 \mathrm{~m}$ & 0.045 & 14.41 & -0.170 & -6.408 & -0.004 & -2.472 & 30.8 \\
$24 \mathrm{~m}$ & 0.043 & 12.45 & -0.157 & -5.095 & -0.001 & -0.437 & 14.5 \\
\hline \hline
\end{tabular}


Table 9: Forecasting monetary policy (Fed funds rate) with option-implied variance and skewness when controlling for macroeconomic fundamentals and stock-market risk aversion

This table shows time-series regressions on monthly Fed funds rate (FFR), using as explanatory variables lagged values of option-implied variance and skewness for maize, wheat and soybeans futures respectively while controlling for macroeconomic fundamentals and stock-market uncertainty. In Panel A we run our predictive regressions on the FFR one month ahead while in panel B we present the regression results when we run the same predictive regressions using a 3-month forecasting horizon. IV is option-implied variance, IS is option-implied skewness, I is the yearly overlapping inflation rate for each month, IPI is the yearly return in the industrial production index, SLOPE is the yield difference between the 10-year US-government bond and the 3-month US-TBill and VIX is the logarithm of the VIX index. The t-statistics reported in parentheses are corrected for autocorrelation and heteroscedasticity using the Newey-West (1987) estimator.

$$
F F R_{t}=b_{0}+b_{1} I V_{t-k}+b_{2} I S_{t-k}+b_{3} V I X_{t-k}+b_{4} I_{t-k}+b_{5} I P I_{t-k}+b_{6} S L O P E_{t-k}+\varepsilon_{t}
$$

Panel A: $k=1$

\begin{tabular}{|c|c|c|c|c|}
\hline & & Maize & Wheat & Soybeans \\
\hline \multirow[t]{2}{*}{ Constant } & Coef. & 0.067 & 0.065 & 0.063 \\
\hline & t-stat & $(3.949)$ & $(4.662)$ & $(3.951)$ \\
\hline \multirow[t]{2}{*}{ Implied Variance } & Coef. & -0.139 & -0.156 & -0.130 \\
\hline & t-stat & $(-2.894)$ & $(-4.607)$ & $(-5.042)$ \\
\hline \multirow[t]{2}{*}{ Implied Skewness } & Coef. & -0.006 & -0.170 & -0.006 \\
\hline & t-stat & $(-3.260)$ & $(-5.219)$ & $(-3.696)$ \\
\hline \multirow[t]{2}{*}{ VIX index } & Coef. & -0.013 & -0.007 & -0.013 \\
\hline & t-stat & $(-1.208)$ & $(-0.831)$ & $(-1.224)$ \\
\hline \multirow[t]{2}{*}{ Inflation } & Coef. & 0.417 & 0.323 & 0.505 \\
\hline & t-stat & $(2.802)$ & $(2.913)$ & $(4.090)$ \\
\hline \multirow[t]{2}{*}{ Industrial Production } & Coef. & 0.011 & 0.008 & -0.001 \\
\hline & t-stat & $(0.223)$ & $(0.211)$ & $(-0.035)$ \\
\hline \multirow[t]{2}{*}{ Term spread (slope) } & Coef. & -1.249 & -1.208 & -1.106 \\
\hline & t-stat & $(-8.072)$ & $(-9.893)$ & $(-7.794)$ \\
\hline \multirow[t]{3}{*}{$\% \mathrm{R}^{2}$ adjusted } & & 62.5 & 73.5 & 65.1 \\
\hline & & Pai & & \\
\hline & & Maize & Wheat & Soybeans \\
\hline \multirow[t]{2}{*}{ Constant } & Coef. & 0.068 & 0.067 & 0.066 \\
\hline & t-stat & $(4.778)$ & $(5.803)$ & $(4.741)$ \\
\hline \multirow[t]{2}{*}{ Implied Variance } & Coef. & -0.124 & -0.149 & -0.127 \\
\hline & t-stat & $(-2.531)$ & $(-4.634)$ & $(-5.316)$ \\
\hline \multirow[t]{2}{*}{ Implied Skewness } & Coef. & -0.006 & -0.016 & -0.005 \\
\hline & t-stat & $(-3.181)$ & $(-4.624)$ & $(-5.342)$ \\
\hline \multirow[t]{2}{*}{ VIX index } & Coef. & -0.015 & -0.009 & -0.015 \\
\hline & t-stat & $(-1.589)$ & $(-1.209)$ & $(-1.528)$ \\
\hline \multirow[t]{2}{*}{ Inflation } & Coef. & 0.338 & 0.248 & 0.421 \\
\hline & t-stat & $(2.206)$ & $(2.227)$ & $(3.255)$ \\
\hline \multirow[t]{2}{*}{ Industrial Production } & Coef. & 0.055 & 0.047 & 0.037 \\
\hline & t-stat & $(1.022)$ & $(1.144)$ & $(0.750)$ \\
\hline \multirow[t]{2}{*}{ Term spread (slope) } & Coef. & -1.169 & -1.136 & -1.039 \\
\hline & t-stat & $(-7.207)$ & $(-8.633)$ & $(-7.090)$ \\
\hline \multicolumn{2}{|l|}{$\% \mathrm{R}^{2}$ adjusted } & 61.7 & 71.8 & 64.6 \\
\hline
\end{tabular}


Table 10: Forecasting monetary policy (goodness of fit of out-of-sample forecasts)

This table shows the out-of-sample adjusted $\mathrm{R}^{2}$ values (in percentages) of our time series regressions on the monetary policy stance. More specifically, we compute the out-of-sample adjusted $\mathrm{R}^{2}$ by estimating dynamic out-of-sample forecasts using an initial 60-month time series window. We run time-series regressions on monthly Fed funds rate (FFR), using as explanatory variables lagged values of optionimplied variance and skewness for maize, wheat and soybeans futures respectively. In Panel A we present the out-of-sample adjusted $\mathrm{R}^{2}$ values when using the risk neutral variance and skewness as predictors of the Fed funds rate, while in Panel B we present the respective out-of-sample adjusted $\mathrm{R}^{2}$ values when controlling for macroeconomic fundamentals and stock-market uncertainty. IV is optionimplied variance, IS is option-implied skewness, I is the yearly overlapping inflation rate for each month, IPI is the yearly return in the industrial production index, SLOPE is the yield difference between the 10-year US-government bond and the 3-month US-TBill and VIX is the logarithm of the VIX index. The t-statistics reported in parentheses are corrected for autocorrelation and heteroscedasticity using the Newey-West (1987) estimator.

Panel A

$$
F F R_{t}=b_{0}+b_{1} I V_{t-k}+b_{2} I S_{t-k}+\varepsilon_{t}
$$

\begin{tabular}{cccc}
\hline \hline Horizon $(\mathrm{k})$ & Maize & Wheat & Soybeans \\
\hline $1 \mathrm{~m}$ & 19.3 & 40.8 & 23.1 \\
$3 \mathrm{~m}$ & 12.5 & 32.6 & 19.7 \\
$6 \mathrm{~m}$ & 4.8 & 21.7 & 12.1 \\
$12 \mathrm{~m}$ & -14.1 & -14.8 & -14.8 \\
$24 \mathrm{~m}$ & -30.1 & -35.4 & -39.9 \\
\hline \hline
\end{tabular}

Panel B

$$
F F R_{t}=b_{0}+b_{1} I V_{t-k}+b_{2} I S_{t-k}+b_{3} V I X_{t-k}+b_{4} I_{t-k}+b_{5} I P I_{t-k}+b_{6} S L O P E_{t-k}+\varepsilon_{t}
$$

\begin{tabular}{cccc}
\hline \hline Horizon $(\mathrm{k})$ & Maize & Wheat & Soybeans \\
\hline $1 \mathrm{~m}$ & 51.1 & 66.2 & 54.5 \\
$3 \mathrm{~m}$ & 43.5 & 58.9 & 46.3 \\
$6 \mathrm{~m}$ & 31.0 & 44.9 & 27.3 \\
$12 \mathrm{~m}$ & -2.4 & -3.5 & -10.6 \\
$24 \mathrm{~m}$ & 7.7 & -1.5 & 5.5 \\
\hline \hline
\end{tabular}


Figure 1. Contemporaneous movements of the Fed funds rate and implied skewness

This graph plots the contemporaneous time series movements of the time series of maize, wheat and soybeans option-implied skewness and the Fed funds rate. The data cover the period from January 1990 to December 2011.
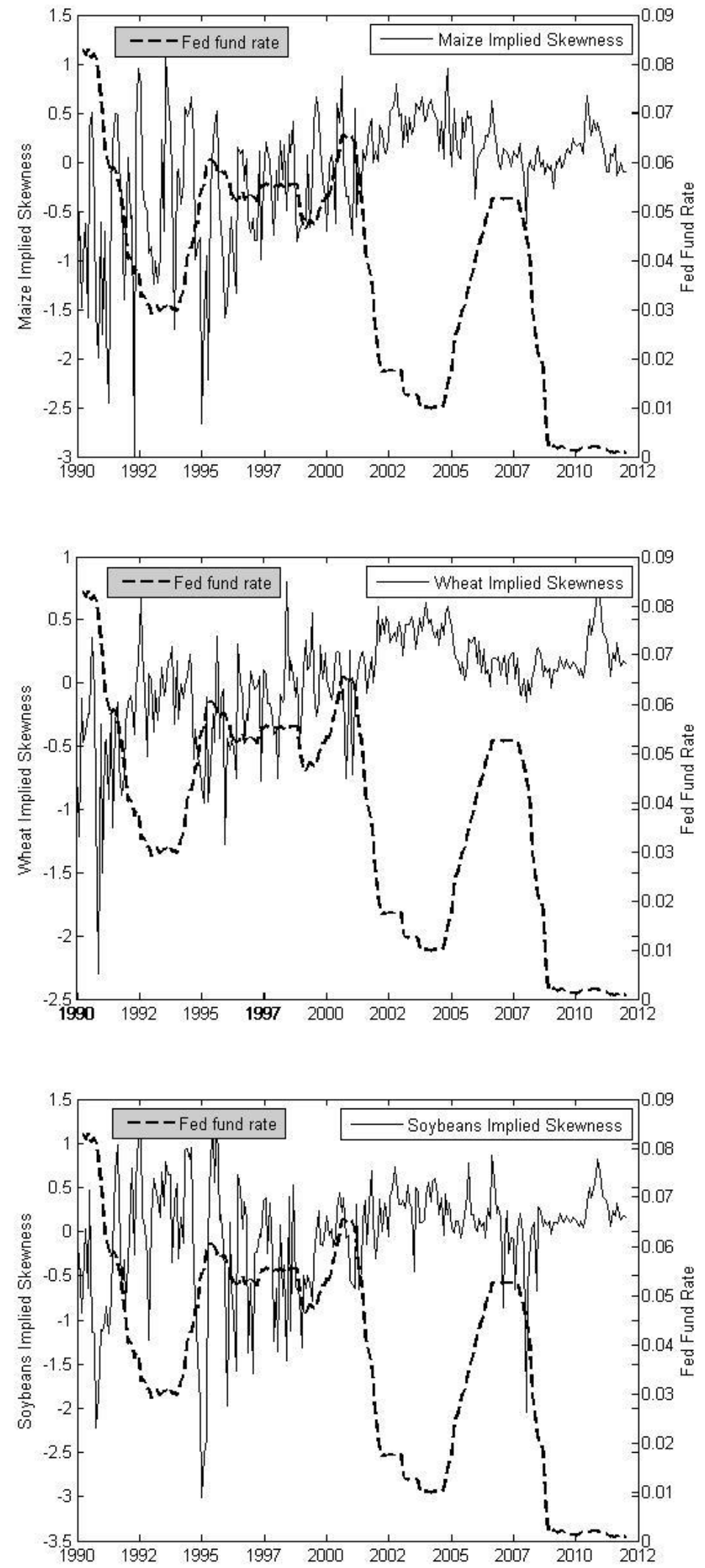
Figure 2. Contemporaneous movements of the Fed funds rate and implied variance

This graph plots the contemporaneous time series movements of the time series of maize, wheat and soybeans option-implied variance and the Fed funds rate. The data cover the period from January 1990 to December 2011.
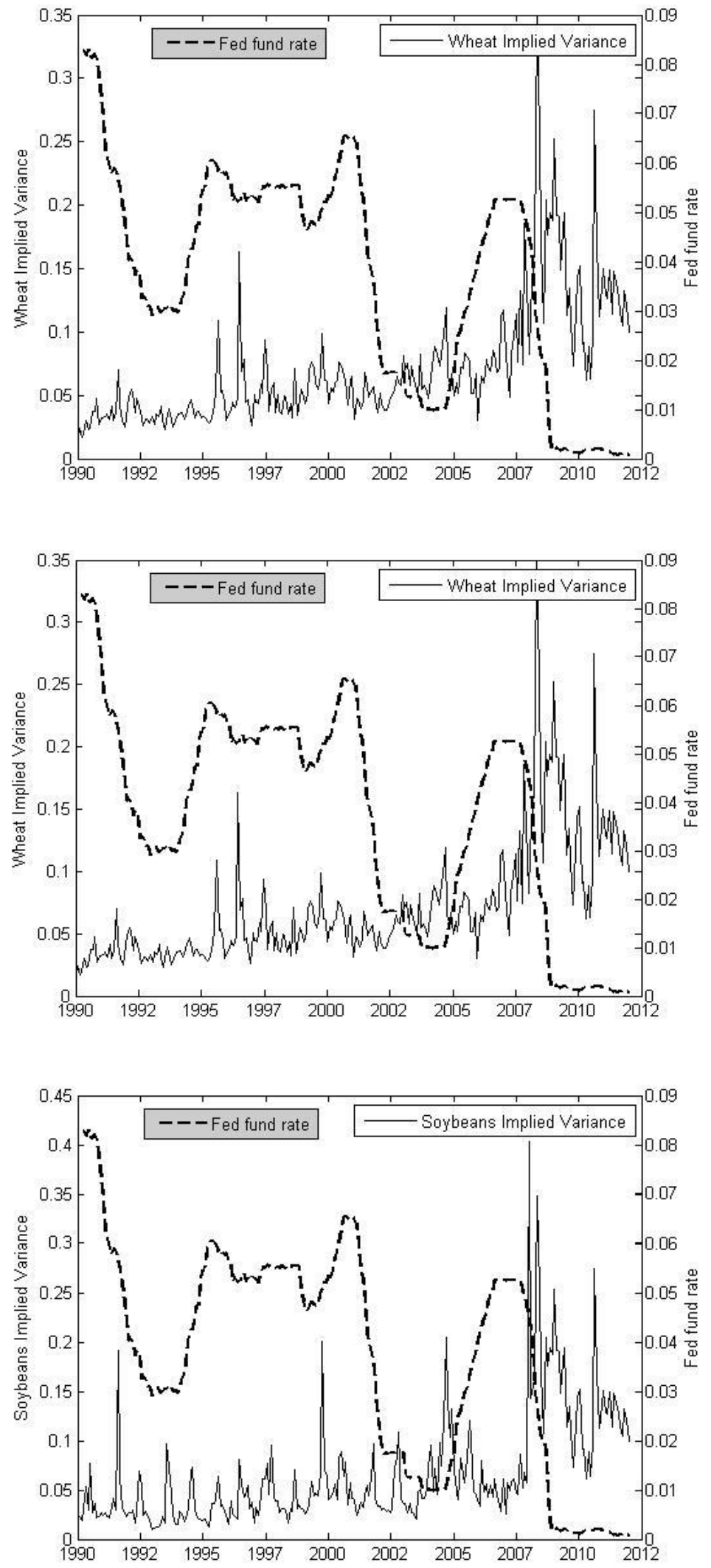
Figure 3. Reduced form Impulse Response Functions (IRFs) between monetary policy (Fed funds rate) and implied variance

This graph shows the Impulse Response Functions (IRFs) of the bivariate structural VARs of the form $Y_{t}=\left[F_{F R} I_{t}\right]$, where FFR is the monthly Fed funds rate and IV is the monthly implied variance of maize, wheat and soybeans markets, respectively. Panel A shows the responses of implied variance to a negative one standard deviation shock to the Fed funds rate, while Panel B shows the responses of the Fed funds rate to a positive shock implied variance of agricultural commodity markets. Both the IRFs of the FFR and the implied variance (IV) of agricultural markets are expressed in percentages (divided by 100). The left column of each Panel shows the responses of the models with the short-run restriction while the right column shows the responses of the models with the long-run restriction. The dashed lines show the $95 \%$ bootstrapped confidence intervals.

\section{PANEL A}

\section{Short-run restriction}

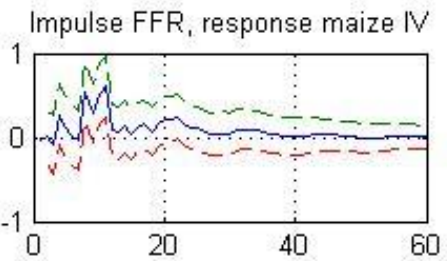

Impulse FFR, response wheat IV

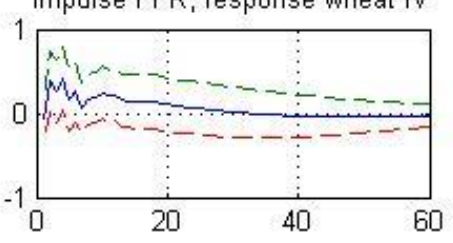

Impulse FFR, response soybeans IV

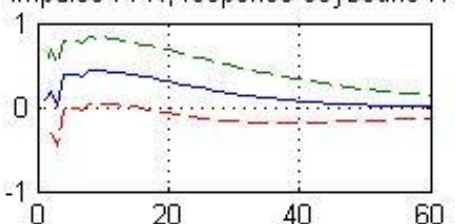

Long-run restriction

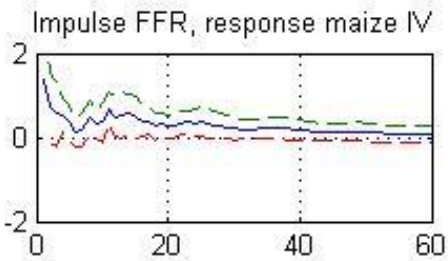

Impulse FFR, response wheat IV

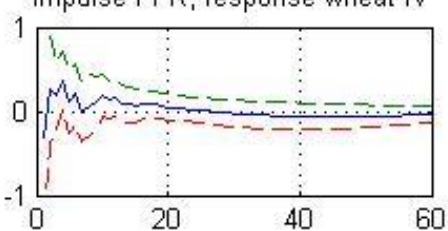

Impulse FFR, response soybeans I

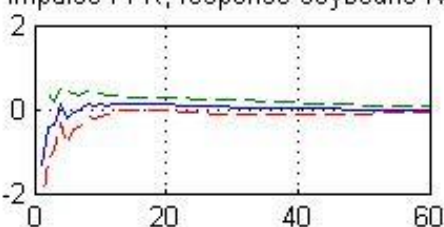

\section{PANEL B}

Short-run restriction

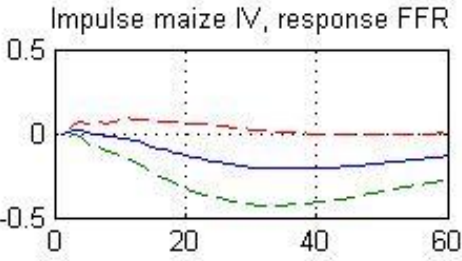

Impulse wheat IV, response FFR

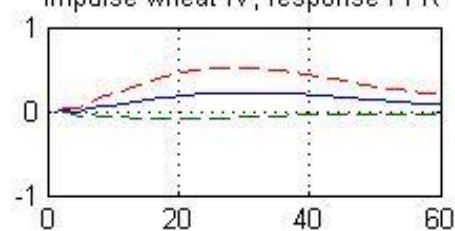

mpulse soybeans $\mathrm{V}$, response $F F$

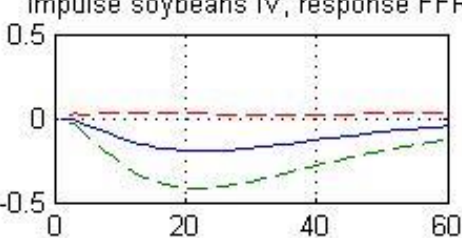

Long-run restriction

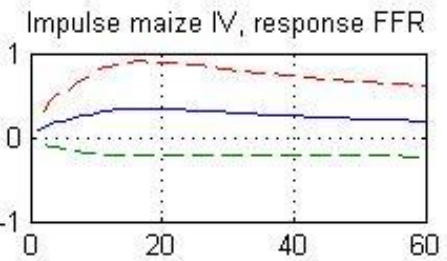

Impulse wheat IV, response FFR

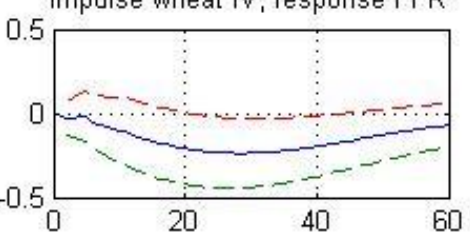

Impulse soybeans $V$, response FFR

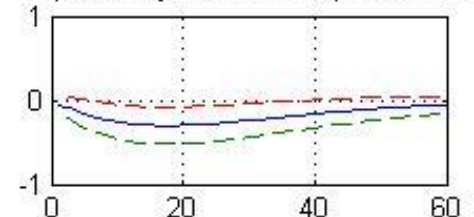




\section{Figure 4. Reduced from Impulse Response Functions (IRFs) between monetary policy (Fed funds rate) and the implied skewness}

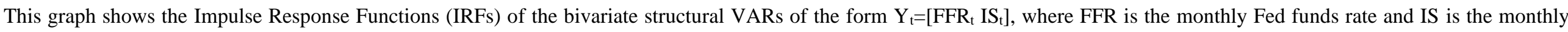

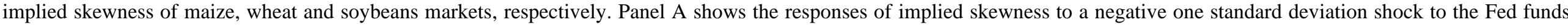

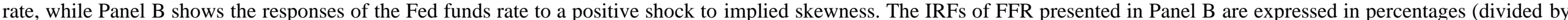

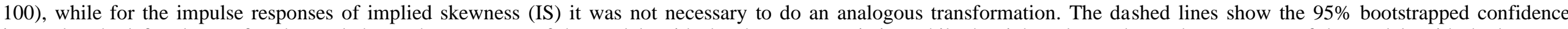

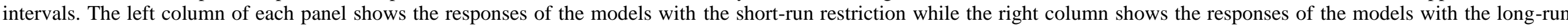
restriction

\section{PANEL A}

\section{PANEL B}

Short-run restriction

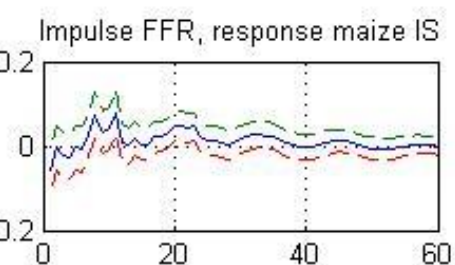

Impulse FFR, response wheat IS

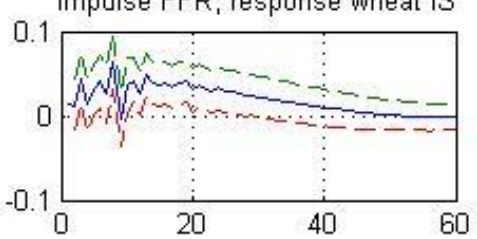

Impulse FFR, response soybeans IS

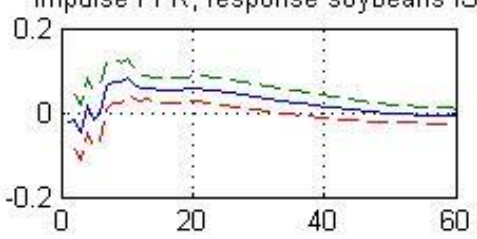

Long-run restriction

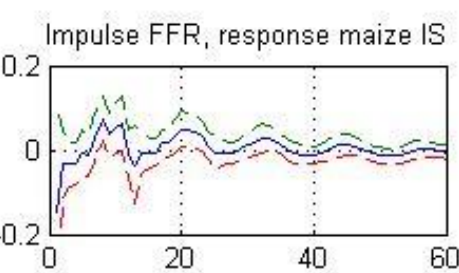

Impulse FFR, response wheat IS

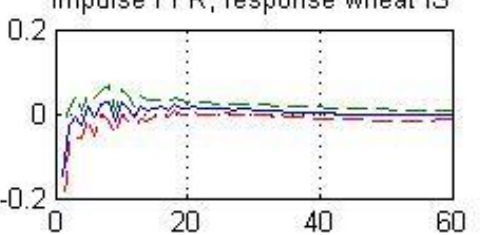

Impulse FFR, response soybeans IS

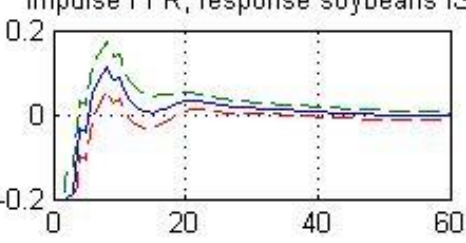

Short-run restriction

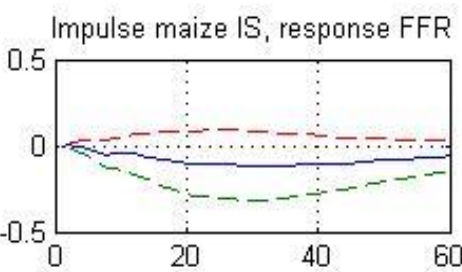

Impulse wheat IS, response FFR

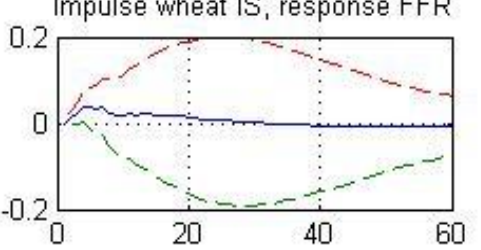

mpulse soybeans IS, response FFR

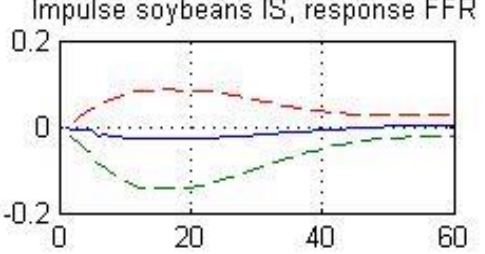

Long-run restriction

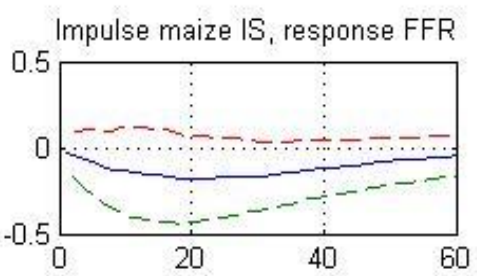

Impulse wheat IS, response FFR

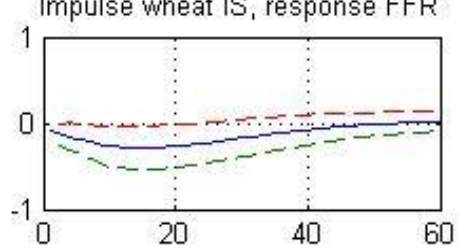

Impulse soybeans IS, response FFR

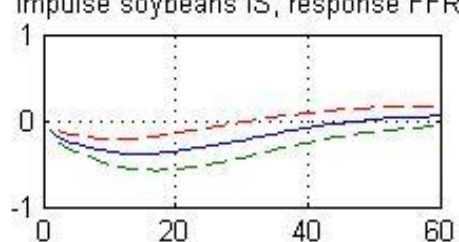




\section{Figure 5. Structural form Impulse Response Functions (SIRFs) between monetary policy (Fed funds rate) and implied variance}

This graph shows the Structural Impulse Response Functions (SIRFs) of the bivariate structural VARs of the form $\mathrm{Y}_{\mathrm{t}}=\left[\mathrm{FFR}_{\mathrm{t}} \mathrm{IV}_{\mathrm{t}}\right]$, where FFR is the monthly Fed funds rate and IV is the monthly implied variance of maize, wheat and soybeans markets, respectively. Panel A shows the responses of implied variance to a negative one standard deviation shock to the Fed funds rate, while Panel B shows the responses of the Fed funds rate to a positive shock implied variance of agricultural commodity markets. The left column of each Panel shows the responses of the models with the short-run restriction while the right column shows the responses of the models with the long-run restriction. The dashed lines show the 95\% bootstrapped confidence intervals.

\section{PANEL A}

Short-run restriction
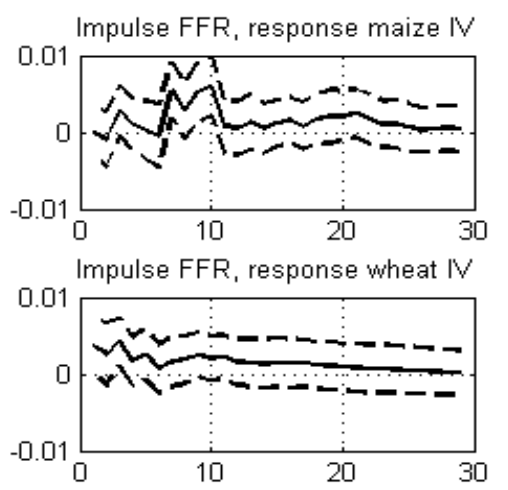

Impulse FFR, response soybeans IV

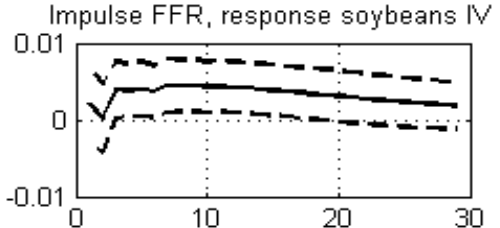

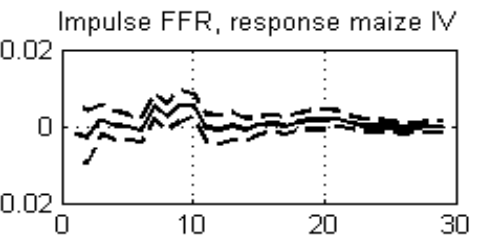

Impulse FFR, response wheat IV

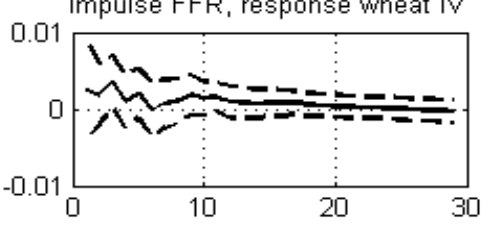

Impulse FFR, response soybeans IV 0.02

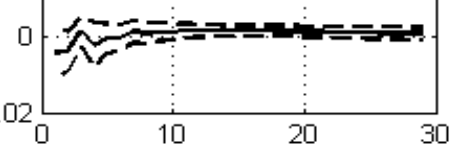

\section{PANEL B}

Short-run restriction

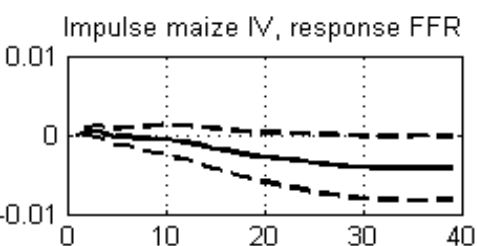

Impulse wheat IV, response FFR

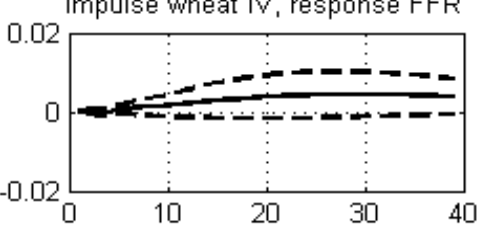

Impulse soybeans $\mathrm{V}$, response FFR

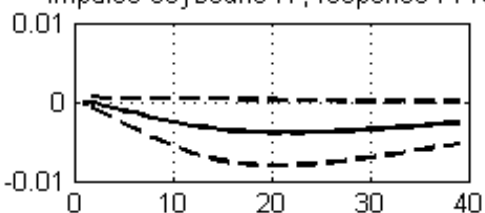

Long-run restriction
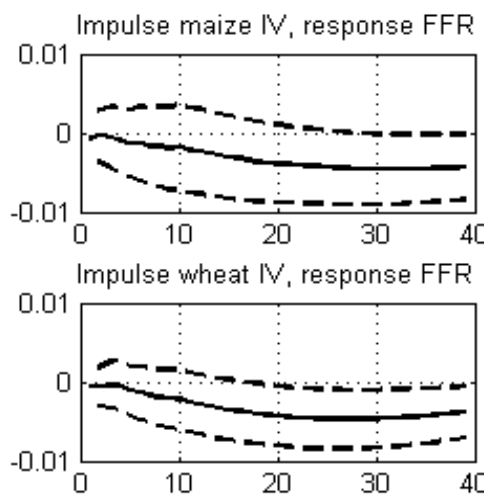

Impulse soybeans IV, response FFR

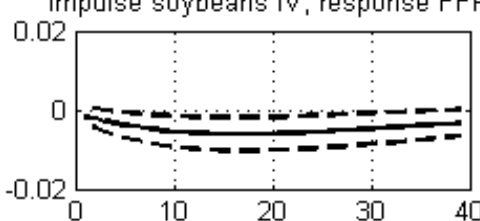


Figure 6. Structural form Impulse Response Functions (SIRFs) between monetary policy (Fed funds rate) and the implied skewness

This graph shows the Structural Impulse Response Functions (SIRFs) of the bivariate structural VARs of the form $\mathrm{Y}_{\mathrm{t}}=\left[\mathrm{FFR}_{\mathrm{t}} \mathrm{IS}_{\mathrm{t}}\right]$, where FFR is the monthly Fed funds rate and IS is the monthly implied skewness of maize, wheat and soybeans markets, respectively. Panel A shows the responses of implied skewness to a negative one standard deviation shock to the Fed funds rate, while Panel B shows the responses of the Fed funds rate to a positive shock to implied skewness. The dashed lines show the 95\% bootstrapped confidence intervals. The left column of each panel shows the responses of the models with the short-run restriction while the right column shows the responses of the models with the long-run restriction.

\section{PANEL A}

\section{PANEL B}

Short-run restriction

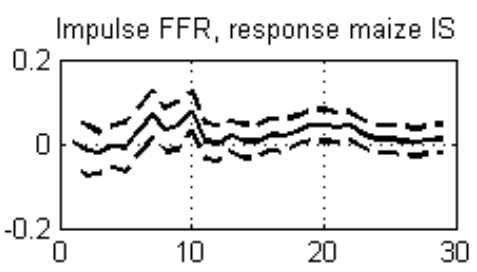

Impulse FFR, response wheat IS

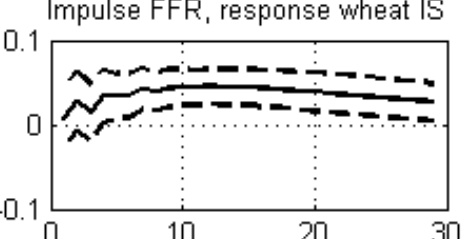

Impulse FFR, response soybeans is

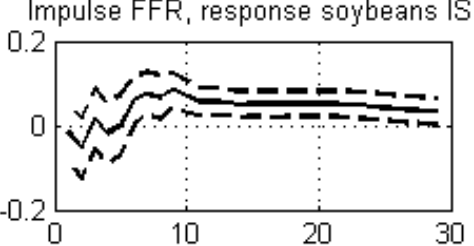

Long-run restriction

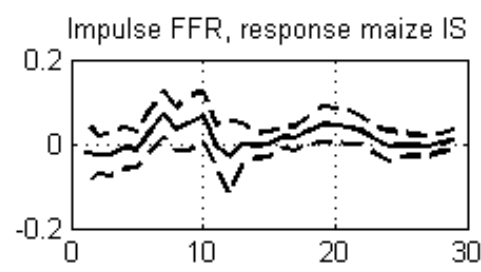

Impulse FFR, response wheat IS

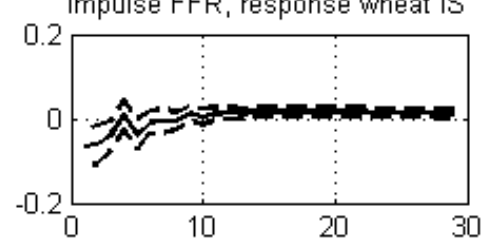

Impulse FFR, response soybeans IS

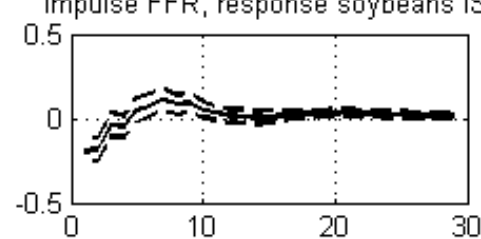

Short-run restriction

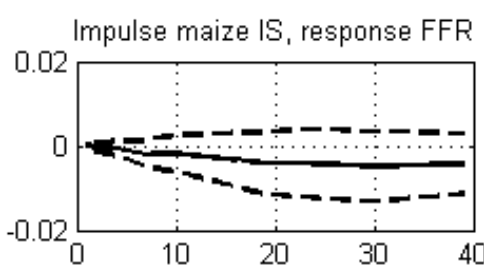

Impulse wheat IS, response FFR

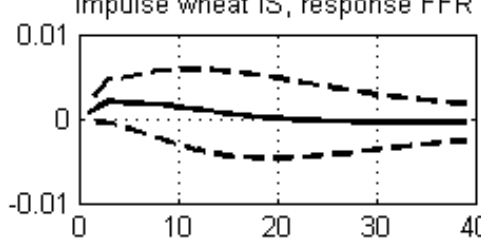

Impulse soybeans IS, response FFR

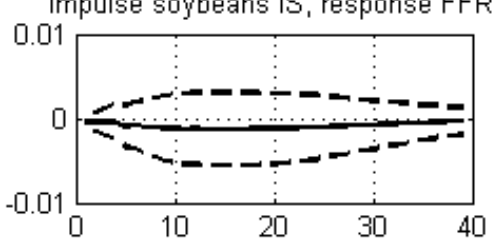

Long-run restriction

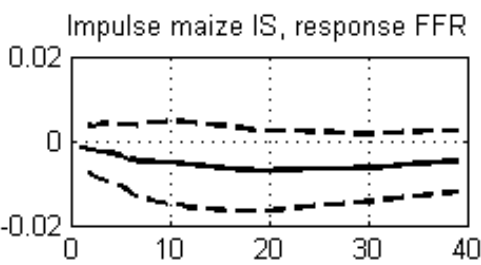

Impulse wheat IS, response FFR

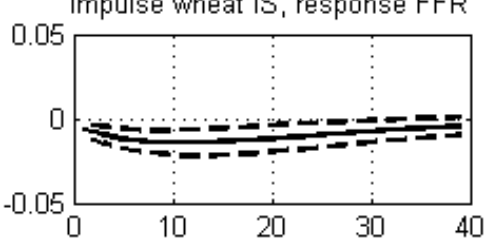

Impulse soybeans IS, response FFR

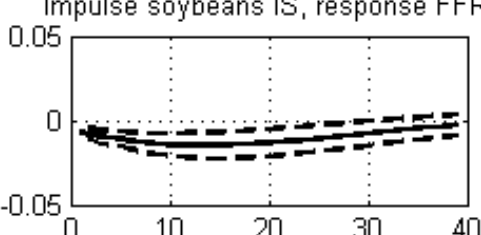

